\title{
Effects of Serine or Threonine in the Active Site of Typical 2-Cys Prx on Hyperoxidation Susceptibility and on Chaperone Activity
}

\author{
Carlos A. Tairum ${ }^{1,2,+}+\mathbb{C}$, Melina Cardoso Santos ${ }^{1,+}\left(\mathbb{0}\right.$, Carlos Alexandre Breyer ${ }^{1,+}+{ }^{\circ}$, Ana Laura Pires de Oliveira ${ }^{1}$, \\ Vitoria Isabela Montanhero Cabrera ${ }^{1}\left(\mathbb{D}\right.$, Guilherme Toledo-Silva ${ }^{3}{ }^{\oplus}$, Gustavo Maruyama Mori ${ }^{4}(\mathbb{D}$, \\ Marcos Hikari Toyama ${ }^{1}\left(\mathbb{D}\right.$, Luis Eduardo Soares Netto ${ }^{2, *(\mathbb{D})}$ and Marcos Antonio de Oliveira $1, *$ (D) \\ 1 Instituto de Biociências, Universidade Estadual Paulista, UNESP, São Vicente 01049-010, Brazil; \\ tairumjr@usp.br (C.A.T.); melina.css@hotmail.com (M.C.S.); carlosbreyer@gmail.com (C.A.B.); \\ alp.oliveira@unesp.br (A.L.P.d.O.); vitoria.isabela.montanhero@gmail.com (V.I.M.C.); \\ marcos.toyama@unesp.br (M.H.T.) \\ 2 Departamento de Genética e Biologia Evolutiva, Instituto de Biociências, Universidade de São Paulo, \\ São Paulo 01049-010, Brazil \\ 3 Laboratório de Biomarcadores de Contaminação Aquática e Imunoquímica, Departamento de Bioquímica, \\ Universidade Federal de Santa Catarina, Florianópolis 88040-900, Brazil; guilherme.toledo@ufsc.br \\ 4 Laboratório de Ecologia Molecular, Instituto de Biociências, Universidade Estadual Paulista, UNESP, \\ São Vicente 01049-010, Brazil; gustavo.mori@unesp.br \\ * Correspondence: nettoles@ib.usp.br (L.E.S.N.); marcos.a.oliveira@unesp.br (M.A.d.O.) \\ + These authors contributed equally to this work.
}

Citation: Tairum, C.A.; Santos, M.C.; Breyer, C.A.; de Oliveira, A.L.P.; Cabrera, V.I.M.; Toledo-Silva, G.; Mori, G.M.; Toyama, M.H.; Netto, L.E.S.; de Oliveira, M.A. Effects of Serine or Threonine in the Active Site of Typical 2-Cys Prx on Hyperoxidation Susceptibility and on Chaperone Activity. Antioxidants 2021, 10, 1032.

https://doi.org/10.3390/antiox10071032

Academic Editor: Bruce Morgan

Received: 5 May 2021

Accepted: 10 June 2021

Published: 25 June 2021

Publisher's Note: MDPI stays neutral with regard to jurisdictional claims in published maps and institutional affiliations.

Copyright: () 2021 by the authors. Licensee MDPI, Basel, Switzerland. This article is an open access article distributed under the terms and conditions of the Creative Commons Attribution (CC BY) license (https:// creativecommons.org/licenses/by/ $4.0 /)$.

\begin{abstract}
Typical 2-Cys peroxiredoxins (2-Cys Prx) are ubiquitous Cys-based peroxidases, which are stable as decamers in the reduced state, and may dissociate into dimers upon disulfide bond formation. A peroxidatic Cys $\left(\mathrm{C}_{\mathrm{P}}\right)$ takes part of a catalytic triad, together with a Thr/Ser and an Arg. Previously, we described that the presence of Ser (instead of Thr) in the active site stabilizes yeast 2-Cys Prx as decamers. Here, we compared the hyperoxidation susceptibilities of yeast 2-Cys Prx. Notably, 2-Cys Prx containing Ser (named here Ser-Prx) were more resistant to hyperoxidation than enzymes containing Thr (Thr-Prx). In silico analysis revealed that Thr-Prx are more frequent in all domains of life, while Ser-Prx are more abundant in bacteria. As yeast 2-Cys Prx, bacterial Ser-Prx are more stable as decamers than Thr-Prx. However, bacterial Ser-Prx were only slightly more resistant to hyperoxidation than Thr-Prx. Furthermore, in all cases, organic hydroperoxide inhibited more the peroxidase activities of 2-Cys Prx than hydrogen peroxide. Moreover, bacterial Ser-Prx displayed increased thermal resistance and chaperone activity, which may be related with its enhanced stability as decamers compared to Thr-Prx. Therefore, the single substitution of Thr by Ser in the catalytic triad results in profound biochemical and structural differences in 2-Cys Prx.
\end{abstract}

Keywords: 2-Cys Prx; catalytic triad; organic hydroperoxides; oligomerization; hyperoxidation; chaperone

\section{Introduction}

Typical 2-Cys peroxiredoxins (2-Cys $\operatorname{Prx}$ ) of the AhpC/Prx1 sub-family are peroxidases widely distributed in prokaryotes and eukaryotes that reduce hydroperoxides with high efficiency [1-4]. These enzymes are very abundant, representing $0.1-1.0 \%$ of all soluble proteins in the cells [5-8] and capable of decomposing distinct hydroperoxides $[9,10]$. Additionally, typical 2-Cys Prx are mediators of redox signaling and can act as molecular chaperones [11-15].

The 2-Cys Prx use a fully conserved N-terminal cysteine residue (peroxidatic cysteine- $C_{P}$ ), which is responsible for the nucleophilic attack on the hydroperoxide and then becomes oxidized into a sulfenic acid $\left(\mathrm{C}_{\mathrm{P}}-\mathrm{SOH}\right)$, which can condensate with a second $\mathrm{Cys}$ residue (resolving cysteine, $\mathrm{C}_{\mathrm{R}}-\mathrm{SH}$ ) forming an intermolecular disulfide $\left(\mathrm{C}_{\mathrm{P}}-\mathrm{S}-\mathrm{S}-\mathrm{C}_{\mathrm{R}}\right)$. In most cases, 
these disulfide bonds are reduced by thioredoxin (Trx) [16-19]. The high reactivity of the $C_{P}$ is related to the microenvironment in which it is found. $C_{P}$ is in close proximity to other two fully conserved residues (Thr/Ser and Arg), forming polar interactions that increase the electrophilicity of $\mathrm{H}_{2} \mathrm{O}_{2}$, and facilitate the nucleophilic attack by the thiolate on $\mathrm{C}_{\mathrm{P}}$ [20]. As expected, $C_{P}[21-23]$, as well as Thr/Ser and Arg [3,23-25], are essential for the efficient reduction of hydroperoxides. Thus, these three residues $\left(\mathrm{C}_{\mathrm{P}}\right.$, Thr/Ser, and Arg) compose the so-called catalytic triad [3,22,26].

Under high hydroperoxide concentrations, $\mathrm{C}_{\mathrm{P}}$ can undergo further oxidation generating hyperoxidized species $\left(\mathrm{C}_{\mathrm{P}}-\mathrm{SO}_{2} \mathrm{H}\right.$ or $\left.\mathrm{C}_{\mathrm{P}}-\mathrm{SO}_{3} \mathrm{H}\right)$ rather than forming the disulfide bond, inactivating Prx turnover by Trx $[27,28]$. However, the enzyme sulfiredoxin (Srx) can reduce $\mathrm{C}_{\mathrm{P}}-\mathrm{SO}_{2} \mathrm{H}$ to $\mathrm{C}_{\mathrm{P}}-\mathrm{SOH}$ in a process dependent on ATP hydrolysis for typical 2-Cys Prx $[27,28]$. Hyperoxidized 2-Cys Prx are frequently associated with a molecular chaperone (holdase) function and may impact signaling pathways, like cell growth and circadian rhythm [29-32]. In addition to $C_{P}$ hyperoxidation, high temperatures can also confer chaperone function to these enzymes [33-36].

A remarkable feature of 2-Cys $\operatorname{Prx}$ is the structural rearrangement that are triggered by $\mathrm{C}_{\mathrm{P}}$ oxidation. Reduced 2-Cys Prx enzymes $\left(\mathrm{C}_{\mathrm{P}}-\mathrm{S}^{-}\right)$are stabilized as decamers $\left[\left(\alpha_{2}\right)_{5}\right]$ and can assume the so called fully folded (FF) state (Figure 1A), in which $C_{P}$ is located in the first turn of an $\alpha$-helix near to $\mathrm{N}$-terminal region of the protein and far away from $C_{R}(10-16 \AA)$, which is located in the C-terminus of these enzymes. Upon oxidation, partial unfolding of the $\alpha$-helix containing $\mathrm{C}_{\mathrm{P}}-\mathrm{SOH}$ (the so-called locally unfolded $=\mathrm{LU}$ state) allows its approximation to $C_{R}$ with the consequent intermolecular disulfide bond formation [37]. In the disulfide form, the 2-Cys Prx decamers tend to dissociate into low molecular weight (LMW) species, mainly dimers [38-40] (Figure 1B). Moreover, when $C_{P}$ is hyperoxidized or when subjected to heat shock, 2-Cys Prx can switch from decamers to higher molecular weight (HMW) species [32,33,35,41,42] (Figure 1C). Therefore, two reversible structural switches (FF-LU and decamers dissociation) are inter-connected and the stabilities of distinct conformers are influenced by thermal and/or redox factors.

The transitions and stability of distinct oligomers also rely in structural peculiarities of these enzymes. In the 2-Cys Prx from Escherichia coli (EcAhpC) mutations close to the C-terminal region precludes the decamer formation [43]. Factors as $\mathrm{pH}$, ionic strength, and protein concentration can influence directly the quaternary state of 2-CysPrx, indicating that the oligomeric rearrangements are directly related to specialized functions of these enzymes in different organisms and cell compartments [39,44-47]. In that regard, we have shown that the presence of Thr or Ser in the catalytic triad influences the stabilities of distinct oligomeric states that 2-Cys Prx can assume [3]. Yeast Tsa1 and Tsa2 contain Thr or Ser in the active site, respectively. Both enzymes are decamers in the reduced state, but Tsa1 is mainly a dimer when oxidized and some are intermediate species (e.g., tetramers), while Tsa2 remains as decamer even after oxidation [3]. In addition, the mutation of catalytic Thr to Ser stabilizes Tsa1 in the decameric form even when oxidized [3]. The substitution of catalytic triad Thr to Ser also stabilizes typical 2-Cys Prx from Salmonella typhimurium and Enterococcus faecalis as decamers $[48,49]$.

Here, we described that the presence of Thr and Ser in the active site also affected the sensibility of 2-Cys Prx to hyperoxidation. Previously, other structural features were described to confer sensibility of $C_{P}$ to hyperoxidation, namely a GGLG motif (close to the active site) and a YF motif (found in a $\alpha$-helix in the C-terminal portion) that are present almost uniquely in eukaryotic enzymes [40]. Posteriorly, the presence of the motif A (D- $\left.\mathrm{X}_{8}-\mathrm{N} / \mathrm{G}-\mathrm{X}_{10}-\mathrm{H}-\mathrm{X}_{27}-\mathrm{S} / \mathrm{G}\right)$ and of the motif B $\left(\mathrm{T}-\mathrm{X}_{3}-\mathrm{S} / \mathrm{T}\right)$ were associated with increased resistance of 2-Cys Prx to hyperoxidation [50]. We show that yeast 2-Cys Prx (AhpC/Prx1 subfamily) with Ser in the catalytic triad (named here Ser-Prx) are more resistant to hyperoxidation than those containing Thr (named here Thr-Prx). Moreover, analysis of all the sequences of typical 2-Cys Prx present in the NCBI GenBank revealed that occurrence of Ser-Prx is rare in multicellular eukaryotes and more frequent in eubacteria. Therefore, we describe that bacterial Ser-Prx were also more stable as decamers and 
displayed more resistance to thermal inactivation than bacterial Thr-Prx. Furthermore, we found that cumene hydroperoxide (CHP) was more efficient than $\mathrm{H}_{2} \mathrm{O}_{2}$ to inactivate both Ser-Prx and Thr-Prx. Finally, we showed that bacterial Ser-Prx retained peroxidase activity and acquired molecular chaperone activity more readily than Thr-Prx after treatment at high temperatures.

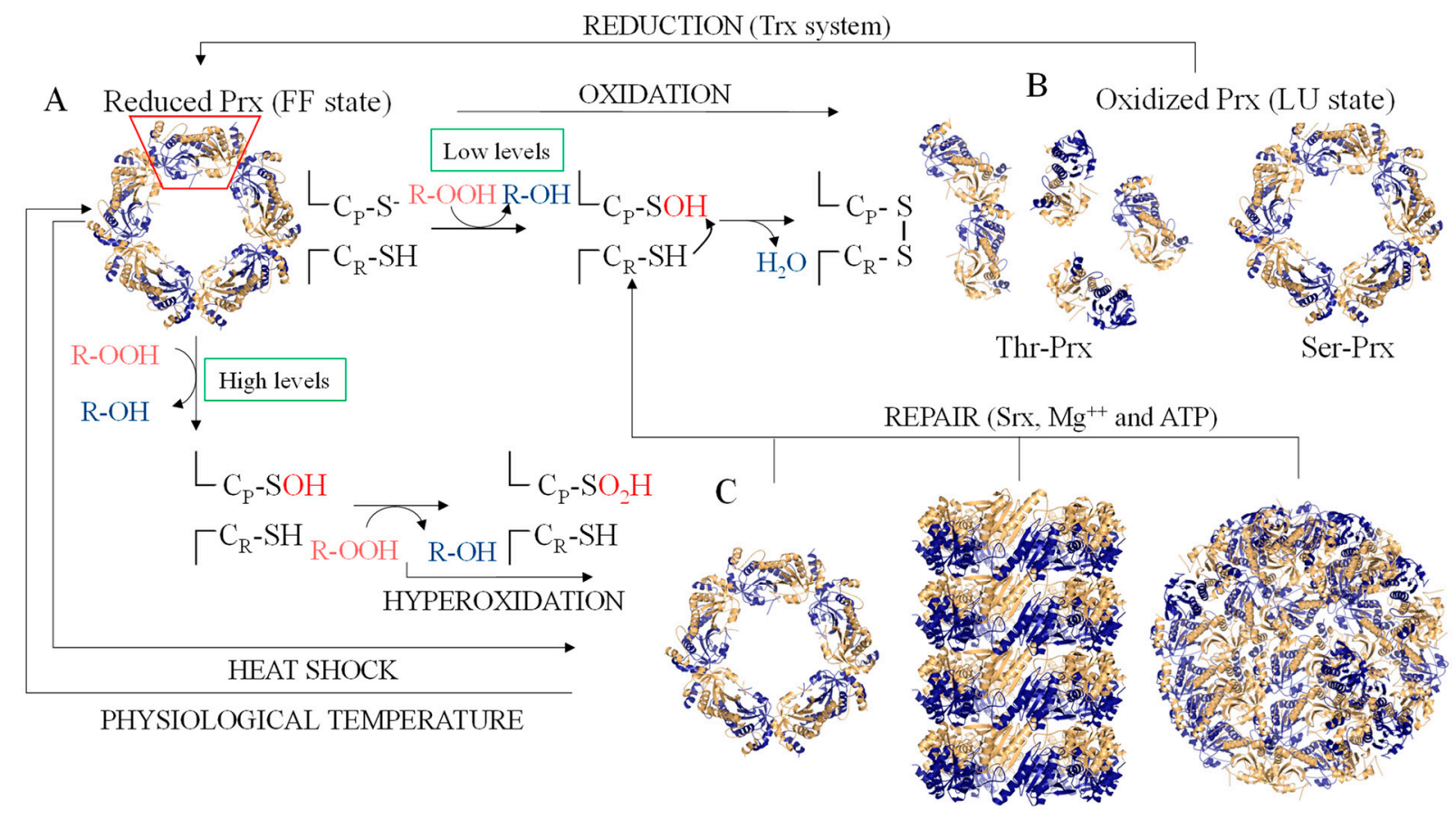

MOLECULAR CHAPERONE

Figure 1. Structural and functional transitions of 2-Cys Prx. (A) In reduced $\left(\mathrm{C}_{\mathrm{P}} \mathrm{S}^{-}\right)$and in the fully folded (FF) state, 2-Cys Prx are decamers formed by association of five homodimers $\left(\alpha_{2}[5]\right)$. The red trapeze denotes one of the homodimers that compose the decamer. The monomers of each homodimer are depicted in dark blue and light orange, represented in cartoon. At low hydroperoxides level, $C_{P}$ is oxidized to sulfenic acid $\left(C_{P}-S O H\right)$ and then the condensation with $C_{R}$ occurs, resulting in the formation of an intermolecular disulfide bond and locking the 2-Cys Prx in the locally unfolded (LU) state. (B) In 2-Cys Prx containing Thr (Thr-Prx), the disulfide formation results in decamer dissociation, while in 2-Cys Prx containing Ser (Ser-Prx), the decamers are stable even in the disulfide form. (C) At high levels of hydroperoxides, $\mathrm{C}_{\mathrm{P}}-\mathrm{SOH}$ can react with another(s) hydroperoxide molecule(s) resulting in hyperoxidized species $\left(\mathrm{C}_{\mathrm{P}}-\mathrm{SO}_{2} \mathrm{H}\right.$ or $\left.\mathrm{C}_{\mathrm{P}}-\mathrm{SO}_{3} \mathrm{H}\right)$ and in the functional switch from peroxidase to chaperone. This functional switch may be accompanied by the appearance of species with molecular weight higher than the decamer. This process can be reversed by Srx, with ATP hydrolysis. The functional transition from peroxidase to chaperone can also be triggered by high temperatures and the peroxidase activity is restored at physiological temperatures. The 2-Cys Prx representations were made using the crystallographic coordinates of Saccharomyces cerevisiae enzyme $(\mathrm{PDB}=3 \mathrm{SBC})$.

\section{Materials and Methods}

\subsection{Amplification, Cloning and Sequencing}

Yeast wild type proteins (Tsa1, Tsa2, Trx1, and TrxR1) were obtained as previously described [3,51]. Bacterial AhpC and the corresponding thiol reductive systems were amplified by PCR from the genomic DNA of the following species/strains: Escherichia coli/ATCC25922, and Pseudomonas aeruginosa/ATCC29853. The ahpc gene from Staphylococcus epidermidis / ATCC12228 was synthesized by GenScript, based on the sequence SE_2357 from KEGG database, with optimized codons for expression in E. coli, and flanked with Nde I and Bam HI restriction sites. Amplified DNA fragments and synthetic gene were digested with Nde I and Bam HI and cloned into pET15b vector previously digested with the same enzymes. The resulting recombinant vectors were sequenced in an ABI 3730 DNA 
Analyzer (Applied Biosystems) using the Big Dye Terminator v3.1 Cycle Sequencing Kit (Applied Biosystems) and then were used to transform E. coli BL21 (DE3) or E. coli Tuner (DE3) strain (Sigma-Aldrich, Taufkirchen, Germany).

\subsection{Site Directed Mutagenesis}

The mutagenesis protocols were performed using Quick Change II Kit (Stratagene), following manufacturer's instructions. The products were used to transform E. coli XL1Blue strain (Agilent Technologies, Santa Clara, CA, USA) and single colonies were grown on Luria Bertani (LB) medium for $16 \mathrm{~h}$. Then, plasmids were extracted, purified, and sequenced. Plasmids containing the expected single substitutions were used to transform E. coli BL21 (DE3) or E. coli BL21 Tuner (DE3) expression strains (Sigma-Aldrich). The BL21 (DE3) strain containing the plasmid pET15b/tsa1 ${ }^{\text {t44s }}$ was previously obtained [3]. All strains used in this work are summarized in Table 1.

Table 1. List of strains used in this work.

\begin{tabular}{|c|c|c|}
\hline Species & Strain/Plasmid & Source \\
\hline E. coli & ATCC25922 & ATCC * \\
\hline E. coli & BL21 DE3/pET15b-ahpc (Pa) & This work \\
\hline E. coli & BL21 DE3/pET15b-ahpc (Se) & This work \\
\hline E. coli & BL21 DE3/pET15b-trx (Ec) & This work \\
\hline E. coli & BL21 DE3/pET15b-trxr (Ec) & This work \\
\hline E. coli & BL21 DE3/pET15b-tsa1 (Sc) & [52] \\
\hline E. coli & BL21 DE3 Tuner/pET15b-tsa2 (Sc) & [3] \\
\hline E. coli & BL21 DE3/pET15b-tsa1t44s (Sc) & [3] \\
\hline E. coli & BL21 DE3 Tuner/pET15b-tsa2s44t (Sc) & This work \\
\hline E. coli & BL21 DE3/pET15b-trx1 (Sc) & [51] \\
\hline E. coli & BL21 DE3/pET15b-trxr1 (Sc) & [51] \\
\hline E. coli & XL1-Blue & Agilent \\
\hline P. aeruginosa & ATCC29853 & ATCC * \\
\hline S. epidermidis & ATCC12228 & ATCC * \\
\hline
\end{tabular}

* American Type Culture Collection; genes: $\mathrm{Ec}=$ E. coli, $\mathrm{Pa}=$ P. aeruginosa, $\mathrm{Sc}=$ S. cerevisiae and Se = Staphylococcus epidermidis.

\subsection{Oligonucleotides}

The oligonucleotides used to cloning and mutagenesis are shown in Table 2.

Table 2. The oligonucleotides sequences were defined based on NCBI genomic DNA sequences NC_000913.3 (E. coli ahpc, trx and trxr), NC_002516.2 (P. aeruginosa ahpc), NZ_CP035288.1 (S. epidermidis ahpc) and NC_001136.10 (S. cerevisiae tsa2).

\begin{tabular}{|c|c|}
\hline Oligonucleotide & Sequence \\
\hline Ec_Trx_F & $5^{\prime}$ CGC GAT CCA TAT GAT GAG CGA TAA AAT TAT TCA CCT GAC T $3^{\prime}$ \\
\hline Ec_Trx_R & 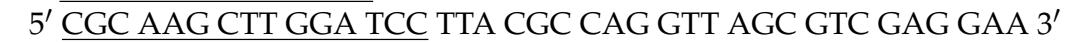 \\
\hline Ec_TrxR_F & $5^{\prime}$ CGC GAT CCA TAT GAT GGG CAC GAC CAA ACA CAG TAA ACT G 3' \\
\hline Ec_TrxR_R & $5^{\prime}$ CGC AAG CTT GGA TCC TTA TTT TGC GTC AGC TAA ACC ATC $3^{\prime}$ \\
\hline $\mathrm{Pa} \_\mathrm{AhpC} \_\mathrm{F}$ & $5^{\prime}$ CGC GAT CCA TAT GAT GTC CCT GAT CAA CAC TCA AGT CCA A $3^{\prime}$ \\
\hline Pa_AhpC_R & $5^{\prime}$ CGC AAG CTT GGA TCC TTA GAT CTT GCC GAC CAG GTC CAG G $3^{\prime}$ \\
\hline Pa_AhpC_T43S_F & $5^{\prime}$ GCT GCC TTC TCC TTC AAC TGC 3' \\
\hline Pa_AhpC_T43S_R & $5^{\prime}$ GCA GTT GAA GGA GAA GGC AGC $3^{\prime}$ \\
\hline Se_AhpC_S46T_F & $5^{\prime}$ GCG GAC TTC ACC TTT GTT TGC 3' \\
\hline Se_AhpC_S46T_R & $5^{\prime}$ GCA AAC AAA GGT GAA GTC CGC $3^{\prime}$ \\
\hline Tsa2S44T_F & 5’ ATT GGC TTT TAC TTT TGT CTG TC 3’ \\
\hline Tsa2S44T_R & $5^{\prime}$ GAC AGA CAA AAG TAA AAG CCA AT $3^{\prime}$ \\
\hline
\end{tabular}




\subsection{Expression and Purification of Recombinant Proteins}

Single colonies of E. coli BL21 (DE3) strain containing the expression plasmids were inoculated in LB medium $(20 \mathrm{~mL})$ containing $0.1 \mathrm{mg}$ ampicillin $/ \mathrm{mL}$ overnight at $37^{\circ} \mathrm{C} / 250 \mathrm{rpm}$, transferred to $1 \mathrm{~L}$ of fresh LB medium, and cultured further until $\mathrm{OD}_{600}$ reached 0.6-0.8. Then the expressions of all proteins were induced by the addition of $0.3 \mathrm{mM}$ IPTG at $37^{\circ} \mathrm{C} / 3 \mathrm{~h} / 250 \mathrm{rpm}$ in orbital shaker. Tsa2 and Tsa2 ${ }^{\mathrm{S} 44 \mathrm{~T}}$ were expressed using similar protocols; however, E. coli Tuner (DE3) was used instead.

Cells were harvested by centrifugation and pellets were resuspended in start buffer ( $50 \mathrm{mM}$ sodium phosphate buffer, $\mathrm{pH}$ 7.4, $50 \mathrm{mM} \mathrm{NaCl}, 20 \mathrm{mM}$ imidazole, and $2 \mathrm{mM}$ PMSF) and disrupted by sonication. The cell extracts were kept in ice during streptomycin sulfate $1 \%$ treatment for $20 \mathrm{~min}$. The supernatants clarified by centrifugation were homogenized by filtration and purified by IMAC using HisTrap column (GE Healthcare, Piscataway, NJ, USA). Imidazole was removed by gel filtration using PD10 Desalting column (GE Healthcare, Piscataway, NJ, USA) and the purity of recombinant proteins was verified by SDS-PAGE. The yeast Trx1 was purified by boiling method as described previously [53].

\subsection{NADPH Oxidation Assay}

The NADPH to $\mathrm{NADP}^{+}$oxidation was monitored at $A_{340 \mathrm{~nm}}$ in $100 \mu \mathrm{L}$ reaction mixtures containing $50 \mathrm{mM}$ HEPES pH 7.4, $100 \mu \mathrm{M}$ DTPA, $1 \mathrm{mM}$ sodium azide, $1 \mu \mathrm{M}$ Prx (Tsa1, Tsa2, or reciprocal mutants), $2 \mu \mathrm{M} \operatorname{Tr} x 1,0.3 \mu \mathrm{M} \operatorname{Tr} x \mathrm{R} 1$, and $150 \mu \mathrm{M}$ NADPH. In some cases, yeast enzymes were replaced by bacterial enzymes (Pseudomonas aeruginosa and Staphylococcus epidermidis AhpC; Escherichia coli Trx and TrxR) at the concentrations described in the legend of the figures. The reactions were initiated by $\mathrm{H}_{2} \mathrm{O}_{2}$ or $\mathrm{CHP}$ addition and the reaction mixtures were incubated at $30^{\circ} \mathrm{C}$ or $37^{\circ} \mathrm{C}$.

\subsection{Western Blot Analysis to Evaluate the $C_{P}$ Hyperoxidation}

To confirm if 2-Cys Prx were inactivated by $C_{P}$ hyperoxidation, we collected samples after NADPH enzymatic assays. Proteins were pre-alkylated with NEM $(50 \mathrm{mM})$ to avoid the formation of artifactual disulfides before non-reducing SDS-PAGE. Samples were then transferred to a nitrocellulose membrane (Bio-Rad, Hercules, CA, USA) and were incubated with an anti-Prx-SO 3 (dilution 1:2500; AbFrontier, Seoul, Korea; \#LF-PA0004) diluted 1000 times in TBST containing 3\% skimmed milk and incubated on a rocking platform for $16 \mathrm{~h}$ at $4{ }^{\circ} \mathrm{C}$. A HRP-conjugated secondary antibody (GE Healthcare-Little Chalfont, UK) was employed and samples were detected by chemiluminescence detection (ECL Prime Western Blot, GE Healthcare-Little Chalfont, UK). Images were obtained by ChemiDoc equipment (Bio-Rad-Hercules, CA, EUA).

\subsection{In Silico Screening of the Typical 2-Cys Prx and Phylogenetic Analyses}

The sequences of the S. cerevisiae Tsa1 (UniProtKB: P34760), Tsa2 (Q04120), Salmonella typhimurium AhpC (P0A251), and Staphylococcus aureus AhpC (P0A0B7) were used as eukaryotic and prokaryotic prototypes of typical 2-Cys Prx containing Thr or Ser in the catalytic triad. These amino acid sequences were used as query against TREMBL database using blastp [54] with a cutoff e-value of $10^{-3}$. Then, to minimize misidentification issues, we identified Pfam domains out of the putative unique orthologs and retained only those presenting the domains found in Tsa1 and Tsa2, AhpC/Prx1 (Pfam: PF00578), redoxin (PF08534) and 1-Cys Prx_C (PF10417) with hmmscan (v.3.1b2) [55]. Sequences presenting other domains, except for SCO1-SenC (PF026300), which we observed in the S. aureus $\mathrm{AhpC}$, were excluded. Additionally, because Prx superfamily presents a conserved activesite cysteine P-X-X-X-(T/S)-X-V-C-P-T-E motif [56], known as $C_{P}-10 o p$ [20], we removed sequences lacking this motif. After these filtering steps, we retrieved taxonomic information of the accessions we obtained from the NCBI taxonomy database (database resources of the National Center for Biotechnology Information; June 2018). 


\subsection{Size Exclusion Chromatography (SEC) of Bacterial Typical 2-Cys Prx}

To obtain reduced samples, $30 \mu \mathrm{M}$ of bacterial 2-Cys Prx were treated with TCEP $5 \mathrm{mM}$ for $60 \mathrm{~min}$ and the TCEP excess was removed using the PD 10 column (reduced samples). To oxidize samples, reduced 2-Cys $\operatorname{Prx}(30 \mu \mathrm{M})$ were treated with $\mathrm{H}_{2} \mathrm{O}_{2}(36 \mu \mathrm{M})$ for $30 \mathrm{~min}$, at room temperature. SEC was performed in an analytical Jasco-HPLC system composed by a PU 2880 Plus injector and a PDA MD 2018 detector. Samples $(30 \mu \mathrm{M}$ in $100 \mathrm{mM}$ Tris- $\mathrm{HCl}$ at $\mathrm{pH}$ 7.4) were separated by a Phenomenex BioSep-SEC-S2000 column $(7.8 \times 300 \mathrm{~mm}$, $5 \mu \mathrm{m}$, resolution range of 15 to $2000 \mathrm{kDa}$ ) (Phenomenex, Inc., Torrance, CA, USA), using a flow of $1 \mathrm{~mL} / \mathrm{min}$ in $100 \mathrm{mM}$ Tris-HCl buffer $\mathrm{pH} 7.4$ monitored by absorbance $(280 \mathrm{~nm})$. Bovine thyroglobulin $(670 \mathrm{kDa})$, bovine gamma globulin $(158 \mathrm{kDa})$, ovalbumin $(44 \mathrm{kDa})$, myoglobin $(17 \mathrm{kDa})$ and vitamin $\mathrm{B}_{12}(1.35 \mathrm{kDa})$ were used as molecular standards (Bio-Rad Laboratories, Richmond, VA, USA).

\subsection{Differential Scanning Fluorimetry}

The thermal unfolding of bacterial 2-Cys Prx were analyzed by using differential scanning fluorimetry (DSF) [57]. Briefly, proteins (final concentration $3 \mu \mathrm{M}$ in $10 \mathrm{mM}$ HEPES pH 7.5, $150 \mathrm{mM} \mathrm{NaCl}$ ) were mixed with $5.25 \mu \mathrm{L}$ of SYPRO Orange dye diluted 200 times in DMSO. Reactions mixtures were equilibrated at $25{ }^{\circ} \mathrm{C}$ for $30 \mathrm{~s}$ and then monitored from $25-95^{\circ} \mathrm{C}$ with increments of $1^{\circ} \mathrm{C} / \min$ for 240 min using an Mx 3005P Real-Time System (Agilent Technologies, Santa Clara, CA, USA,) with excitation and emission filters set to 465 and $590 \mathrm{~nm}$, respectively. The melting temperature $\left(T_{\mathrm{m}}\right)$ of AhpCs were obtained with the MxPro software and curves fit in GraphPad Prism (GraphPad Software, San Diego, CA, USA) using the Boltzmann equation to determine the midpoint of thermal denaturation $\left(T_{\mathrm{m}}\right)$. All measurements were carried out in triplicate and presented as mean $\pm \mathrm{SD}$.

\subsection{Chaperone Activity Assay}

Chaperone (holdase) activities of bacterial 2-Cys Prx were analyzed by their ability to inhibit thermally induced aggregation of citrate synthase (CS) as previously described [34]. Briefly, CS $(2 \mu \mathrm{M})$ was mixed with AhpC at molar ratio 20:1 in $40 \mathrm{mM}$ HEPES-KOH pH 7.5. We also evaluated the differences in chaperone ability of enzymes that were previously heated $\left(48^{\circ} \mathrm{C}\right.$ for $\left.1 \mathrm{~h}\right)$. As negative control, samples without the 2-Cys Prx were used. CS aggregation was monitored by light scattering at $360 \mathrm{~nm}$ using a Synergy H1 microplate reader (BioTek, Winooski, VT, USA). The assay was executed at $43^{\circ} \mathrm{C}$, with continuously shaking (fast double orbital), with reads at each $15 \mathrm{~s}$ for $90 \mathrm{~min}$.

\subsection{Analysis of Crystallographic Structures}

The Prx quaternary structures were accessed from the protein structure database (www.rcsb.org accessed on 5 May 2021). The molecular 3D representations were generated using the PyMOL tool (www.pymol.org accessed on 5 May 2021).

\section{Results}

\subsection{Presence of a Ser in the Catalytic Triad Increased Resistance of Yeast 2-Cys Prx to Hyperoxidation}

Previously, we observed that the presence of a Ser residue in the catalytic triad stabilized yeast 2-Cys Prx in the decameric state even in the disulfide form [3]. Here, we investigated if the presence of a Ser or Thr in the catalytic triad might also affect the hyperoxidation susceptibilities of these enzymes.

The decrease of NADPH consumption at increasing hydroperoxides concentrations $\left(\mathrm{H}_{2} \mathrm{O}_{2}\right.$ in Figure 2 and CHP in Figure 3$)$ is consistent with 2-Cys Prx inhibition by $\mathrm{C}_{\mathrm{P}}$ hyperoxidation. Tsa1 (a Thr-Prx) was remarkably more susceptible to inactivation (Figure 2A) when compared to Tsa2 (a Ser-Prx) (Figure 2C). At concentrations higher than $1 \mathrm{mM}, \mathrm{H}_{2} \mathrm{O}_{2}$ significantly inhibited Tsa1 (Figure 2A), while high doses of $\mathrm{H}_{2} \mathrm{O}_{2}(10 \mathrm{mM})$ did not inactivate Tsa2 (Figure $2 \mathrm{C}$ ). Then, NADPH assays with mutant proteins (Tsa1 ${ }^{\mathrm{T} 44 \mathrm{~S}}$ and $\mathrm{Tsa}^{\mathrm{S}}{ }^{\mathrm{S} 4 \mathrm{~T}}$ ) 
were performed. Tsa1 ${ }^{\mathrm{T} 44 \mathrm{~S}}$ (Figure 2B) was more resistant to $\mathrm{H}_{2} \mathrm{O}_{2}$ inactivation than wild type Tsa1 (Figure 2A). In contrast, $\mathrm{Tsa}^{\mathrm{S}}{ }^{\mathrm{S4} \mathrm{T}}$ (Figure 2D) was more susceptible to inactivation than wild type Tsa2 (Figure 2C). Therefore, these results indicated that Thr-Prx are more susceptible to hyperoxidation than Ser-Prx.

A

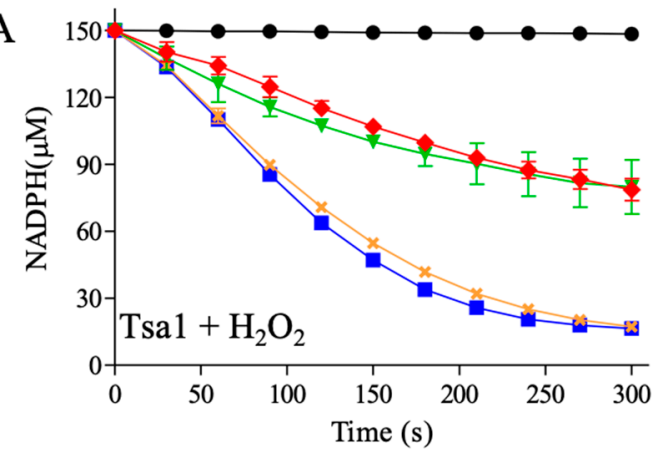

$\mathrm{C}$

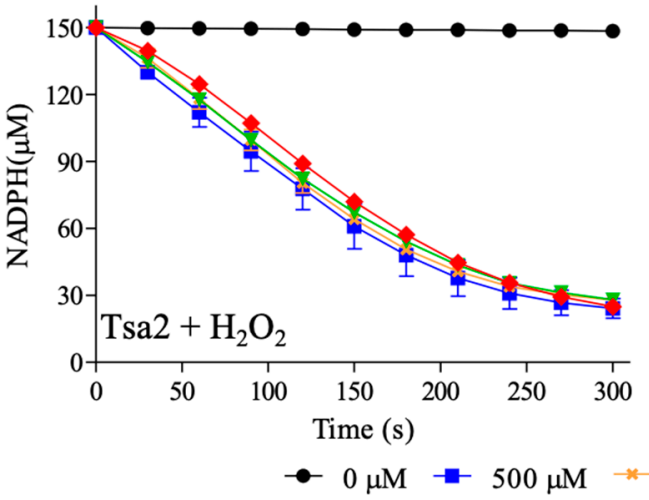

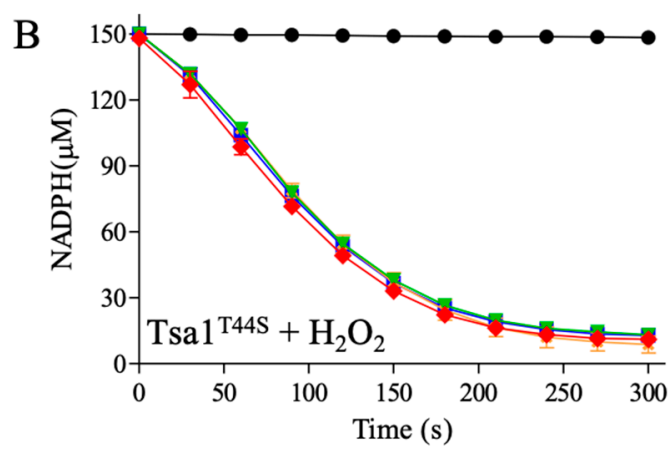

$\mathrm{D}$

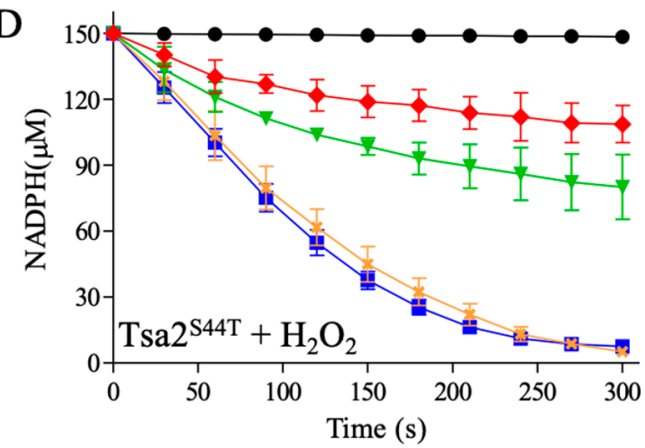

Figure 2. Tsa1, Tsa2, and mutant inhibition by $\mathrm{H}_{2} \mathrm{O}_{2}$. S. cerevisiae Tsa1 (A), Tsa1 ${ }^{\mathrm{T} 44 \mathrm{~S}}(\mathbf{B})$, Tsa2 (C), or Tsa2 ${ }^{\mathrm{S} 44 \mathrm{~T}}$ (D) were exposed to increasing amounts of $\mathrm{H}_{2} \mathrm{O}_{2}$. The assays were performed with $1 \mu \mathrm{M} \operatorname{Prx}, 2 \mu \mathrm{M} \operatorname{Trx} 1,0.3 \mu \mathrm{M} \operatorname{Tr} x \mathrm{R} 1$, and increased amounts of $\mathrm{H}_{2} \mathrm{O}_{2}(0 \mu \mathrm{M}=\bullet$ black, $500 \mu \mathrm{M}=\boldsymbol{\square}$ blue, $1 \mathrm{mM}=\times$ orange, $5 \mathrm{mM}=\boldsymbol{\nabla}$ green and $10 \mathrm{mM}=\boldsymbol{\text { red }})$ in buffer containing $50 \mathrm{mM}$ HEPES pH 7.4, $100 \mu \mathrm{M}$ DTPA, $1 \mathrm{mM}$ sodium azide and $150 \mu \mathrm{M}$ NADPH. The decrease in NADPH absorbance was followed at $340 \mathrm{~nm}$. The error bars represent the standard deviation. All the experiments were performed in triplicate and repeated at least three times with similar results.

We then verified the susceptibilities of these yeast 2-Cys Prx to hyperoxidation by an organic hydroperoxide (CHP). The peroxidase activities of Thr-Prx were almost abolished in all concentrations tested for Tsa1 (Figure 3A) and Tsa2 ${ }^{\mathrm{S} 44 \mathrm{~T}}$ (Figure 3D). In contrast, Ser-Prx were considerably more resistant to inactivation (Figure $3 \mathrm{~B}, \mathrm{C}$ ).

We confirmed that 2-Cys Prx inactivation occurred due to $C_{P}$ hyperoxidation, by western blot assays using anti- $\mathrm{SO}_{3} \mathrm{H}$ antibody (Supplementary Material, Figure S1) from aliquots of samples described in Figures 2 and 3. Hyperoxidized 2-Cys Prx migrated as a dimer $(\sim 46 \mathrm{kDa})$ in non-reducing SDS-PAGE, when one of the active sites was in the disulfide form and the other with the $\mathrm{C}_{\mathrm{P}}$ hyperoxidized $\left(\mathrm{C}_{\mathrm{P}}-\mathrm{SO}_{3} \mathrm{H}\right)$ or as monomer, when all $C_{P s}$ were hyperoxidized.

Two aspects deserve to be highlighted from these results. As already observed [58], Tsa1 is more sensitive to hyperoxidation by $\mathrm{CHP}$ than to $\mathrm{H}_{2} \mathrm{O}_{2}$ (Figures $2 \mathrm{~A}$ and $3 \mathrm{~A}$ ). We now observed that the same characteristic for Tsa2 (Figures $2 \mathrm{C}$ and $3 \mathrm{C}$ ). Additionally, we verified that Ser-Prx (Tsa2 and Tsa1 ${ }^{\mathrm{T} 44 \mathrm{~S}}$ ) are more resistant to hyperoxidation than Thr-Prx (Tsa1 and Tsa2 ${ }^{\mathrm{S}}{ }^{4 \mathrm{~T}}$ ) (Figures 2 and 3 ). Accordingly, $\Delta t s a 2$ yeast strains are more sensitive to organic hydroperoxides than $\Delta t s a 1$ [59]. 

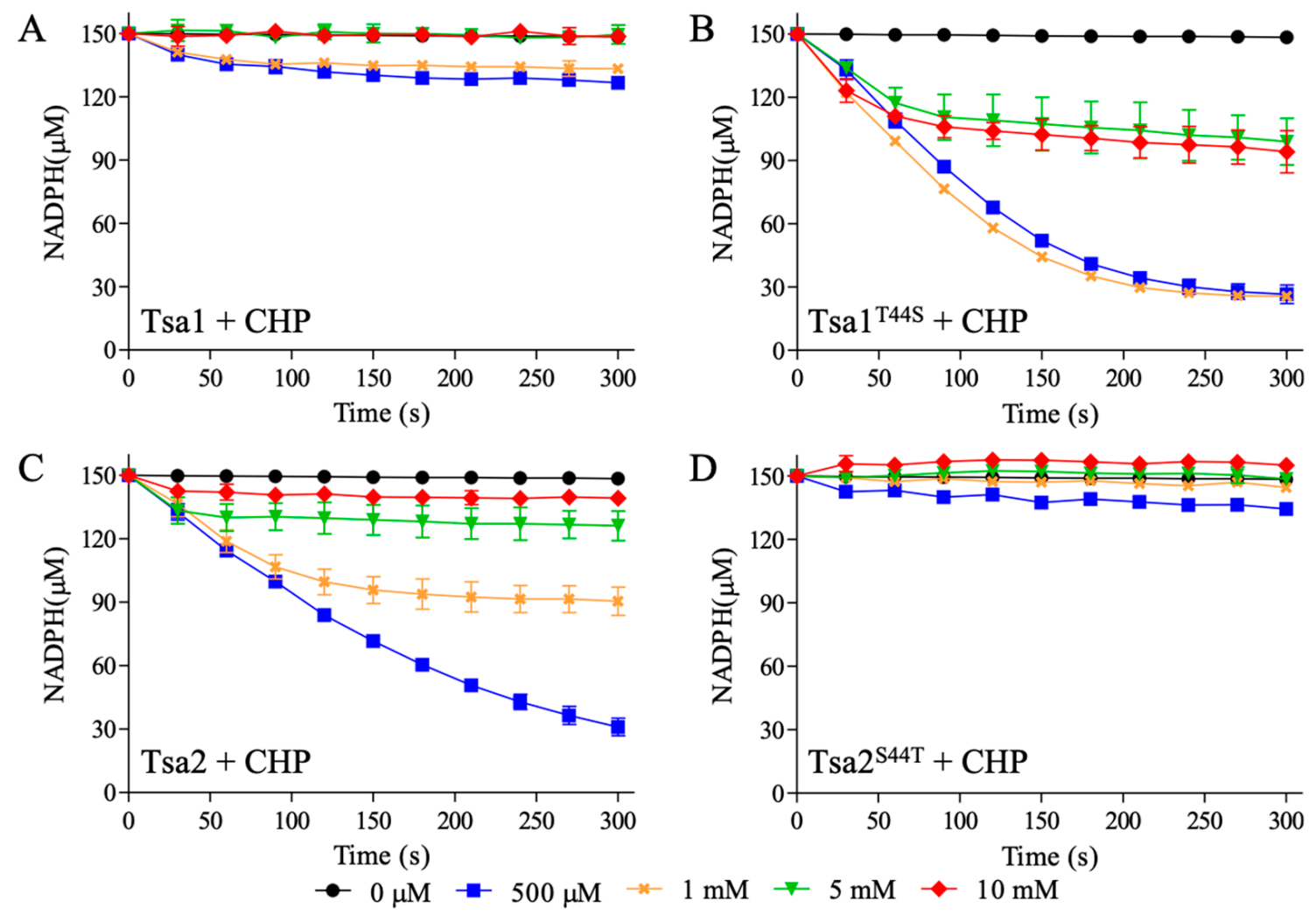

Figure 3. Inactivation of yeast Tsa1, Tsa2, and mutants by CHP. Similar to Figure 2, S. cerevisiae Tsa1 (A), Tsa1 ${ }^{\mathrm{T} 44 \mathrm{~S}}$ (B), $\mathrm{Tsa} 2(\mathbf{C})$, or Tsa2 ${ }^{\mathrm{S} 44 \mathrm{~T}}$ (D) were treated with growing amounts of CHP and the absorbance of NADPH was monitored at $340 \mathrm{~nm}$. The experiment was executed with $1 \mu \mathrm{M}$ Prx, $2 \mu \mathrm{M}$ Trx1, $0.3 \mu \mathrm{M}$ TrxR1 and increased amounts of CHP $(0 \mu \mathrm{M}=\bullet$ black, $500 \mu \mathrm{M}=\boldsymbol{\nabla}$ blue, $1 \mathrm{mM}=\times$ orange, $5 \mathrm{mM}=\boldsymbol{\nabla}$ green and $10 \mathrm{mM}=\boldsymbol{}$ red $)$ in buffer containing $50 \mathrm{mM}$ HEPES pH 7.4, $100 \mu \mathrm{M}$ DTPA, 1 mM sodium azide, and $150 \mu \mathrm{M}$ NADPH. Error bars represent the standard deviations. All the experiments were performed in triplicate and repeated at least three times with similar results.

\subsection{Thr-Prx Are More Widely Distributed and Ser-Prx Is More Prevalent in Bacteria}

As the presence of Ser or Thr provokes dramatic alterations in the biochemical and structural properties of yeast 2-Cys Prx, we investigated the phylogenetic distribution of Ser-Prx and Thr-Prx. We analyzed 45,939 unique protein sequences, out of which 15,034 accessions presented AhpC-TSA, Redoxin and 1-CysPrx_C domains denominations according to Pfam and no other domain fused, except for SCO1-SenC. Out of the sequences with taxonomic annotation at domain level, Thr-Prx represented the majority $(14,092$ sequences, approximately $93.7 \%$ ), whereas the remaining (941 sequences, approximately $6.3 \%$ ) are Ser-Prx (Table 3). Notably, the proportions between Thr-Prx and Ser-Prx are different in the three domains of life. Ser-Prx sequences are proportionally more representative in bacteria $(7.4 \%)$ compared to eukaryotes $(2.7 \%)$ and archaea (1.4\%) (Figure 4$)$. We also found 45 Thr-Prx records deposited in the NCBI database obtained by metagenome approaches and three of them were uncategorized. 
Table 3. Distribution of Thr-Prx or Ser-Prx among the living groups.

\begin{tabular}{|c|c|c|c|c|c|c|c|}
\hline \multicolumn{4}{|c|}{ Thr } & \multicolumn{4}{|c|}{ Ser } \\
\hline \multicolumn{2}{|l|}{ Bacteria } & \multicolumn{2}{|c|}{ Eukarya } & \multicolumn{2}{|c|}{ Bacteria } & \multicolumn{2}{|c|}{ Eukarya } \\
\hline Acidobacteria & 15 & Alveolata & 107 & FCB group * & 14 & Amoebozoa & 1 \\
\hline Aquificae & 16 & Amoebozoa & 83 & Proteobacteria & 15 & Euglenozoa & 12 \\
\hline Calditrichaeota & 2 & Apusozoa & 2 & PVC group $\S$ & 12 & Opisthokonta & 75 \\
\hline Chrysiogenetes & 1 & Cryptophyta & 1 & Spirochaetes & 2 & Rhodophyta & 2 \\
\hline Deferribacteres & 5 & Euglenozoa & 105 & Synergistetes & 1 & & \\
\hline Elusimicrobia & 18 & Heterolobosea & 1 & $\begin{array}{l}\text { Terrabacteria } \\
\text { group }\end{array}$ & 803 & & \\
\hline Environmental samples & 3 & Opisthokonta & 2079 & Unclassified & 4 & & \\
\hline FCB group * & 1455 & $\begin{array}{l}\text { Parabasalia } \\
\text { (parabasalids) }\end{array}$ & 13 & & & & \\
\hline Fusobacteria & 78 & Rhizaria & 4 & & & & \\
\hline $\begin{array}{l}\text { Nitrospinae/Tectomicrobia } \\
\text { group }\end{array}$ & 11 & Rhodophyta & 116 & & & & \\
\hline Nitrospirae & 15 & Stramenopiles & 136 & & & & \\
\hline Proteobacteria & 4890 & Viridiplantae & 302 & & & & \\
\hline PVC group & 220 & & & & & & \\
\hline Spirochaetes & 149 & & & & & & \\
\hline Synergistetes & 10 & & & & & & \\
\hline Terrabacteria group & 3564 & & & & & & \\
\hline Thermodesulfobacteria & 2 & & & & & & \\
\hline Unclassified & 245 & & & & & & \\
\hline
\end{tabular}

* Superphylum that comprises Fibrobacteres, Chlorobi, and Bacteroidetes phyla, $\$$ Superphylum that comprises Planctomycetes, Verrucomicrobia, and Chlamydiae phyla.

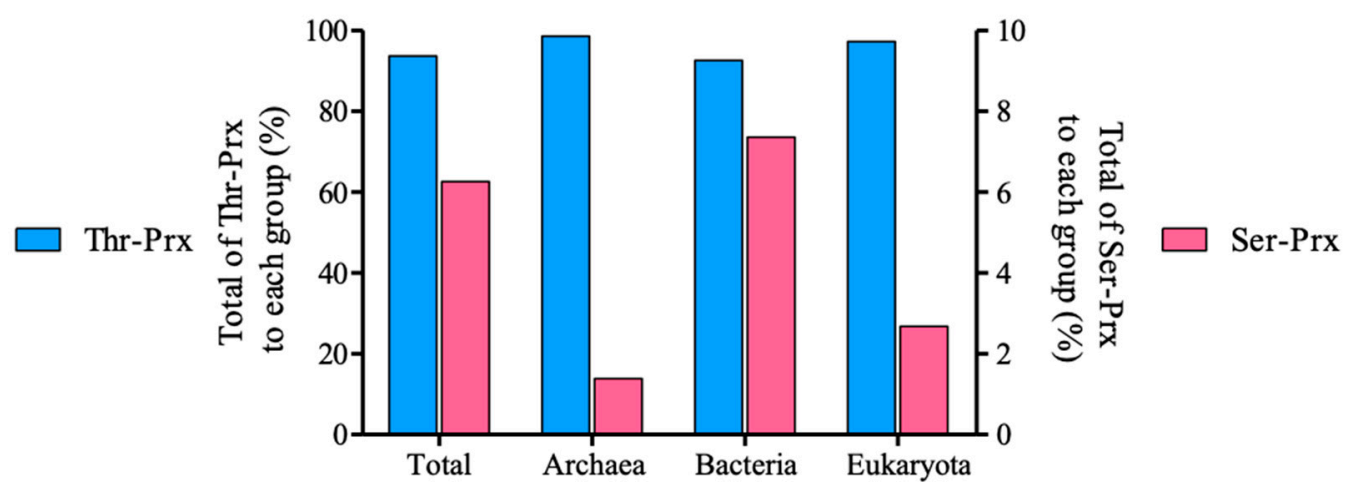

Figure 4. Distribution of the typical 2-Cys Prx containing Thr or Ser as part of the catalytic triad. The analysis of 15,034 unique sequences of typical 2-Cys from the NCBI revealed 14,092 Thr-Prx (93.7\%) and 941 Ser-Prx (6.3\%) sequences. Considering each domain, Ser-Prx are more abundant at bacteria $(7.4 \%)$, followed by eukaryotes $(2.7 \%)$, and archaea (1.4\%). The left Y-axis is referent to Thr-Prx, while right Y-axis is related to Ser-Prx.

The number of sequences of Archaea 2-Cys Prx deposited in the database is very low compared to the other domains of life. Nevertheless, the number of Thr-Prx (71) from Archaea is superior to that of Ser-Prx (1). Thr-Prx are also more widely distributed in Eukarya (2949 representatives present in 12 Superphyla groups) than Ser-Prx ( 90 sequences found in only four groups) (Table 3). For instance, only one species presents Ser-Prx in chordates (killifish Fundulus heteroclitus), whereas a wide range of tetrapods presented only Thr-Prx (See Supplementary Material, Spreadsheet S1).

Concerning bacteria, 16 Superphyla groups contain Thr-Prx, with the prevalence of the Proteobacteria followed by Sphingobacteria (FCB group) and Thermodesulfobacteria groups. Conversely, Ser-Prx occurs with striking predominance in the Terrabacteria group (Table 3). Curiously, Thr-Prx are distributed similarly in Gram negative and Gram positive, whereas Ser-Prx are found mostly in Gram negative (Actinobacteria and Firmicutes). 
Additionally, as S. cerevisiae, some bacteria (e.g., Bacillus subtilis) possess both Thr-Prx and Ser-Prx isoforms [60], as S. cerevisiae.

\subsection{Quaternary Structures Characterization of Bacterial Thr-Prx and Ser-Prx}

Considering the higher abundance of Ser-Prx in Bacteria, we evaluated the role of $\mathrm{Thr} /$ Ser in AhpC enzymes. We selected to analyze recombinant AhpCs from Pseudomonas aeruginosa (PaAhpC-a Thr-Prx) and AhpC from Staphylococcus epidermidis (SeAhpC-a Ser-Prx), as they belong to the most abundant groups of Thr-Prx (Proteobacteria) and of Ser-Prx (Terrabacteria). As with yeast 2-Cys Prx, we performed reciprocal Ser-Thr mutations and we carried out SEC analysis of bacterial 2-Cys Prx. While PaAhpC was mostly decamer in the reduced form and dimer when oxidized (Figure 5A), PaAhpC ${ }^{\mathrm{T} 44 \mathrm{~S}}$ was predominantly decamer when oxidized or reduced (Figure 5B). Similarly, yeast Tsa1 and Salmonella typhimurium AhpC (both Thr-Prx) are decamers when reduced and dimers when oxidized in disulfides, while the substitution of Thr to Ser confers higher stability to the decamer even when the 2-Cys Prx are oxidized [3,39,49].
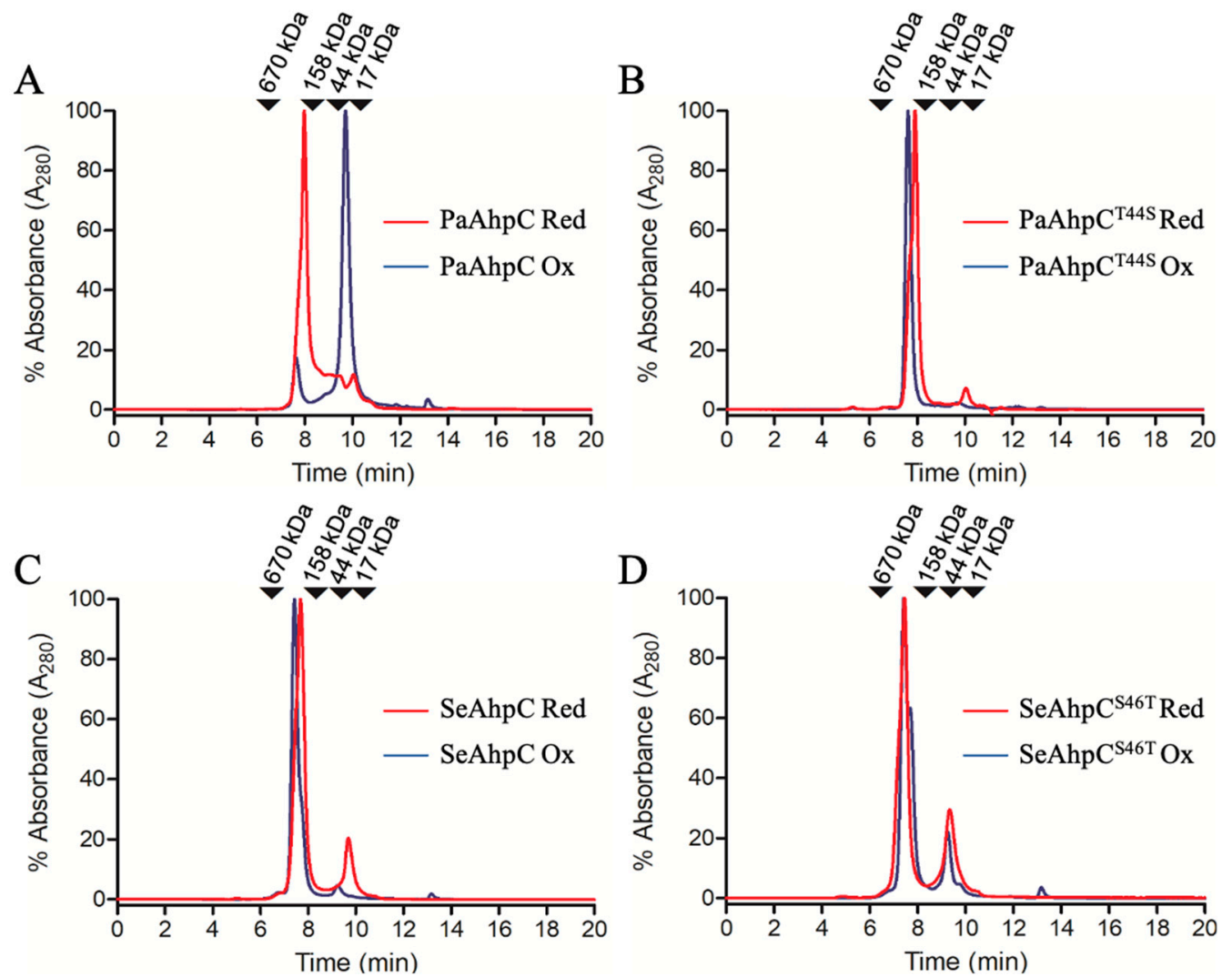

Figure 5. Size exclusion chromatography of PaAhpC and SeAhpC and Thr/Ser mutants. PaAhpC (A), PaAhpC ${ }^{\text {T44S }}$ (B), SeAhpC (C), and SeAhpC $C^{S 46 \mathrm{~T}}$ (D), at a final concentration of $30 \mu \mathrm{M}$, were treated with TCEP $5 \mathrm{mM}$ (red lines) or $\mathrm{H}_{2} \mathrm{O}_{2}$ $36 \mu \mathrm{M}$ (blue lines) for $30 \mathrm{~min}$, at room temperature, before being submitted to SEC. The elution profile was monitored at a wavelength of $280 \mathrm{~nm}$, at flow rate of $1 \mathrm{~mL} / \mathrm{min}$. Bovine thyroglobulin (670 kDa), bovine gamma globulin (158 kDa), ovalbumin $(44 \mathrm{kDa})$, and myoglobin $(17 \mathrm{kDa})$ were used as molecular standards. The experiments were performed at least three times.

Similarly to other Ser-Prx [3,48], SeAhpC was presented mostly as decamer independently of the redox state although a small amount of dimers was present in the reduced form (Figure 5C). Additionally, most of SeAhpC ${ }^{\mathrm{S} 46 \mathrm{~T}}$ was presented as decamer and only a small fraction of the enzyme was detected as dimers, independently of the redox state (Figure 5D). It has been shown by SEC and TEM that the AhpC from Enterococcus faecalis, a naturally Ser-Prx, is a decamer independent of the redox state [43], similarly to yeast 
Tsa2 [3]. Thus, our results showed that the presence of Thr or Ser in the catalytic triad is a relevant factor related to the redox sensitive oligomerization, but additional features also interfere with the quaternary assembly of typical 2-Cys $\operatorname{Prx}[43,45,61]$.

\subsection{Comparative Analysis of the Inactivation of Bacterial Thr-Prx and Ser-Prx by High Hydroperoxide Concentrations and by Thermal Insult}

We also investigated if the presence of Thr or Ser in the catalytic triad could affect the susceptibility of bacterial 2-Cys Prx to hyperoxidation. In the experimental conditions tested, $\mathrm{H}_{2} \mathrm{O}_{2}$ did not inhibit the NADPH consumption in the reaction mixtures containing Thr-Prx (Figure 6A,D) or Ser-Prx (Figure 6B,C) even at the highest doses (10 mM). However, when CHP was the substrate, a slight inhibition was observed to Thr-Prx (compare Figure $6 \mathrm{E}, \mathrm{F}$ and Figure $6 \mathrm{G}, \mathrm{H})$. Again, we confirmed that the inhibition of peroxidase activity was a consequence of the $\mathrm{C}_{\mathrm{P}}$ hyperoxidation by western blot analysis performed using anti-SO $\mathrm{S}_{3}$ antibody (Supplementary Material, Figure S2).

As the inhibition to bacterial Thr-Prx was less evident in relation to eukaryotic counterparts, we compared the NADPH consumption after $300 \mathrm{~s}$ from the data presented in Figure 2, Figure 3, and Figure 6 (Figure 7). For the yeast enzymes, we observed that NADPH consumption is quite similar between Thr-Prx and Ser-Prx at lower $\mathrm{H}_{2} \mathrm{O}_{2}$ concentrations, but it is considerably higher in samples containing Ser-Prx when 5 or $10 \mathrm{mM}$ $\mathrm{H}_{2} \mathrm{O}_{2}$ were used (Figure 7A). When CHP was the substrate, the NADPH consumption was also more evident for Ser-Prx (Figure 7B). For the bacterial enzymes, there was no clear difference among the enzymes (Figure $7 \mathrm{C}$ ). However, we could detect a lower NADPH consumption for Thr-Prx (PaAhpC and SeAhpC ${ }^{\text {S46T }}$ ) compared to the reciprocal Ser$\operatorname{Prx}\left(\mathrm{PaAhpC} \mathrm{C}^{\mathrm{T} 43 \mathrm{~S}}\right.$ and SeAhpC) (Figure 7D). These results indicate that bacterial Ser-Prx present a subtle resistance to hyperoxidation to $\mathrm{CHP}$, but not to $\mathrm{H}_{2} \mathrm{O}_{2}$ compared to the bacterial Thr-Prx.

We also evaluated the inactivation of Thr-Prx and Ser-Prx by thermal stress. The differential scanning fluorimetry (DSF) curve for PaAhpC presented a lag phase and the determined $T_{\mathrm{m}}$ was $58.5 \pm 1.4^{\circ} \mathrm{C}$, while PaAhpC $\mathrm{C}^{\mathrm{T} 44 \mathrm{~S}}$ displayed a sudden increase in the fluorescence and the $T_{\mathrm{m}}$ of $66.1 \pm 2.3^{\circ} \mathrm{C}$ (Figure $8 \mathrm{~A}$ ). Therefore, replacement of the catalytic triad Thr by Ser resulted in an increase about $8{ }^{\circ} \mathrm{C}$ in the $T_{\mathrm{m}}$ (Figure $8 \mathrm{~A}$ ). For SeAhpC and SeAhpC $C^{\mathrm{S} 46 \mathrm{~T}}$, the shapes of the thermal sigmoidal profiles were very similar, although the Ser to Thr substitution resulted in a decrease of $\approx 9{ }^{\circ} \mathrm{C}$ of the $T_{\mathrm{m}}(61.3 \pm 0.5$ and $52.7 \pm 0.6^{\circ} \mathrm{C}$, respectively) (Figure $8 \mathrm{~B}$ ). Therefore, the presence of Ser in the catalytic triad increased the thermal stabilities of the AhpCs.

Since the thermal stability increased in Ser-Prx, we tested if the proteins retained their peroxidase activities after the thermal pre-treatments. The Thr-Prx (PaAhpC and SeAhpC ${ }^{\mathrm{S} 46 \mathrm{~T}}$ ) were partially inactivated after being heated to $55^{\circ} \mathrm{C}$ (Figure 9A,D).

However, the effect of temperature was much more noticeable for SeAhpC ${ }^{\mathrm{S} 46 \mathrm{~T}}$, where the pre-treatment at $55^{\circ} \mathrm{C}$ abolished the peroxidase activity of the enzyme (Figure 9D). This result agreed with the determined $T_{\mathrm{m}}$ values, as the enzyme SeAhpC ${ }^{\mathrm{S} 46 \mathrm{~T}}$ displayed the lowest $T_{\mathrm{m}}$ value. On the other hand, the Ser-Prx (PaAhpC ${ }^{\mathrm{T} 43 S}$ and SeAhpC) retained the activity in all temperatures tested (Figure 9B,C). 

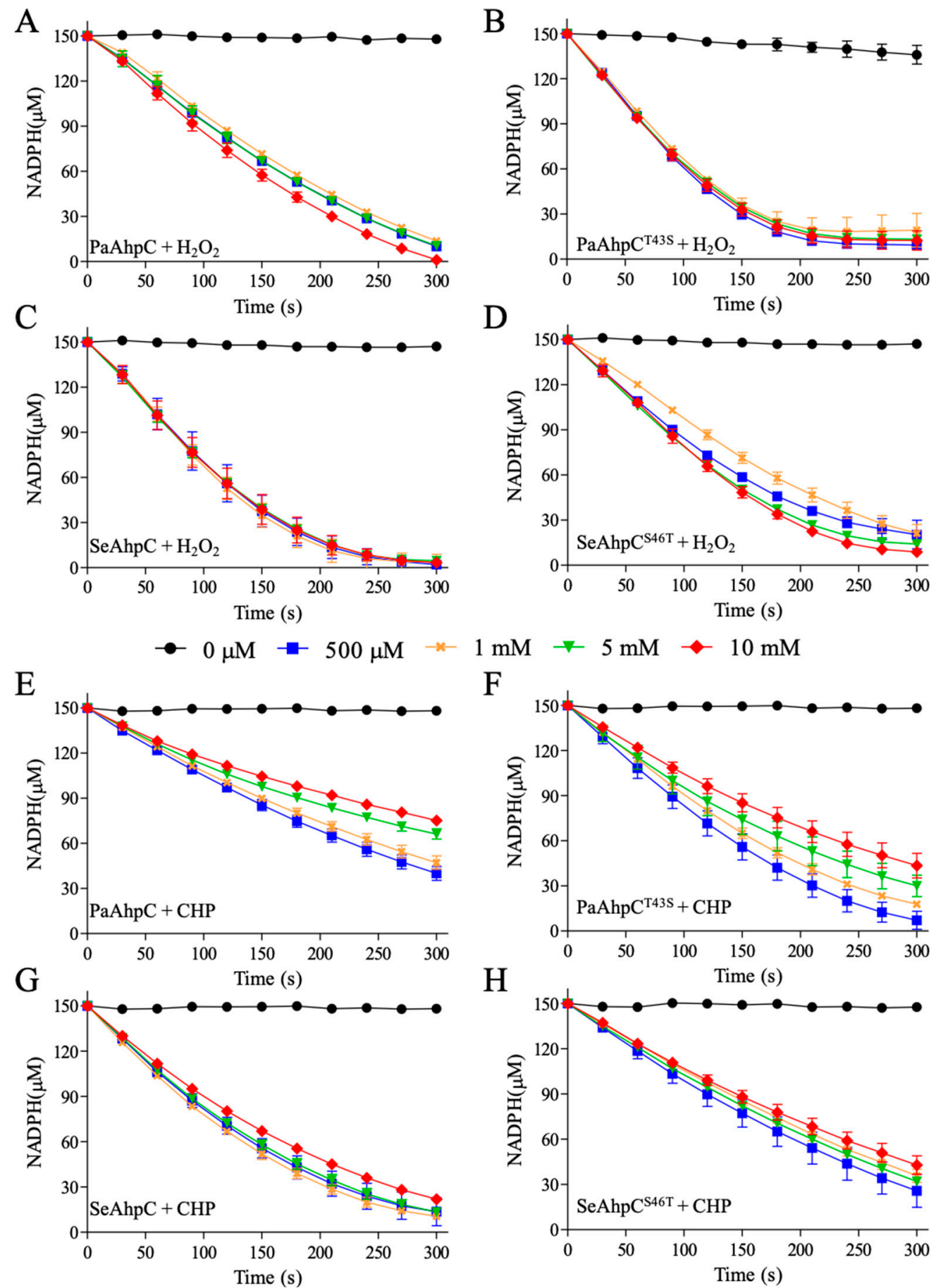

Figure 6. NADPH oxidation assay for evaluation of AhpC hyperoxidation of P. aeruginosa and S. epidermidis using the heterologous E. coli Trx system. Reactions were executed containing PaAhpC (A,E), PaAhpC ${ }^{\text {T43S }}$ (B,F), SeAhpC (C,G), or SeAhpC $C^{\text {S46T }}(\mathbf{D}, \mathbf{H})(3 \mu \mathrm{M})$, EcTrx $(6 \mu \mathrm{M})$, EcTrxR $(0.9 \mu \mathrm{M}), \mathrm{NADPH}(150 \mu \mathrm{M}), 50 \mathrm{mM}$ HEPES pH 7.4, 1 mM sodium azide, and $100 \mu \mathrm{M}$ DTPA. The experiments were started adding growing concentrations of $\mathrm{H}_{2} \mathrm{O}_{2}(\mathbf{A}-\mathbf{D})$ or $\mathrm{CHP}(\mathbf{E}-\mathbf{H})(0 \mu \mathrm{M}=\bullet$ black, $500 \mu \mathrm{M}=\boldsymbol{\square}$ blue, $1 \mathrm{mM}=\times$ orange, $5 \mathrm{mM}=\boldsymbol{\nabla}$ green and $10 \mathrm{mM}=\checkmark$ red). The reactions were incubated for $5 \mathrm{~min} / 37^{\circ} \mathrm{C}$. The oxidation of NADPH was monitored spectrophotometrically at $340 \mathrm{~nm}$. The error bars represent the standard deviations. All experiments were performed in triplicate and repeated at least three times, yielding consistent results. 

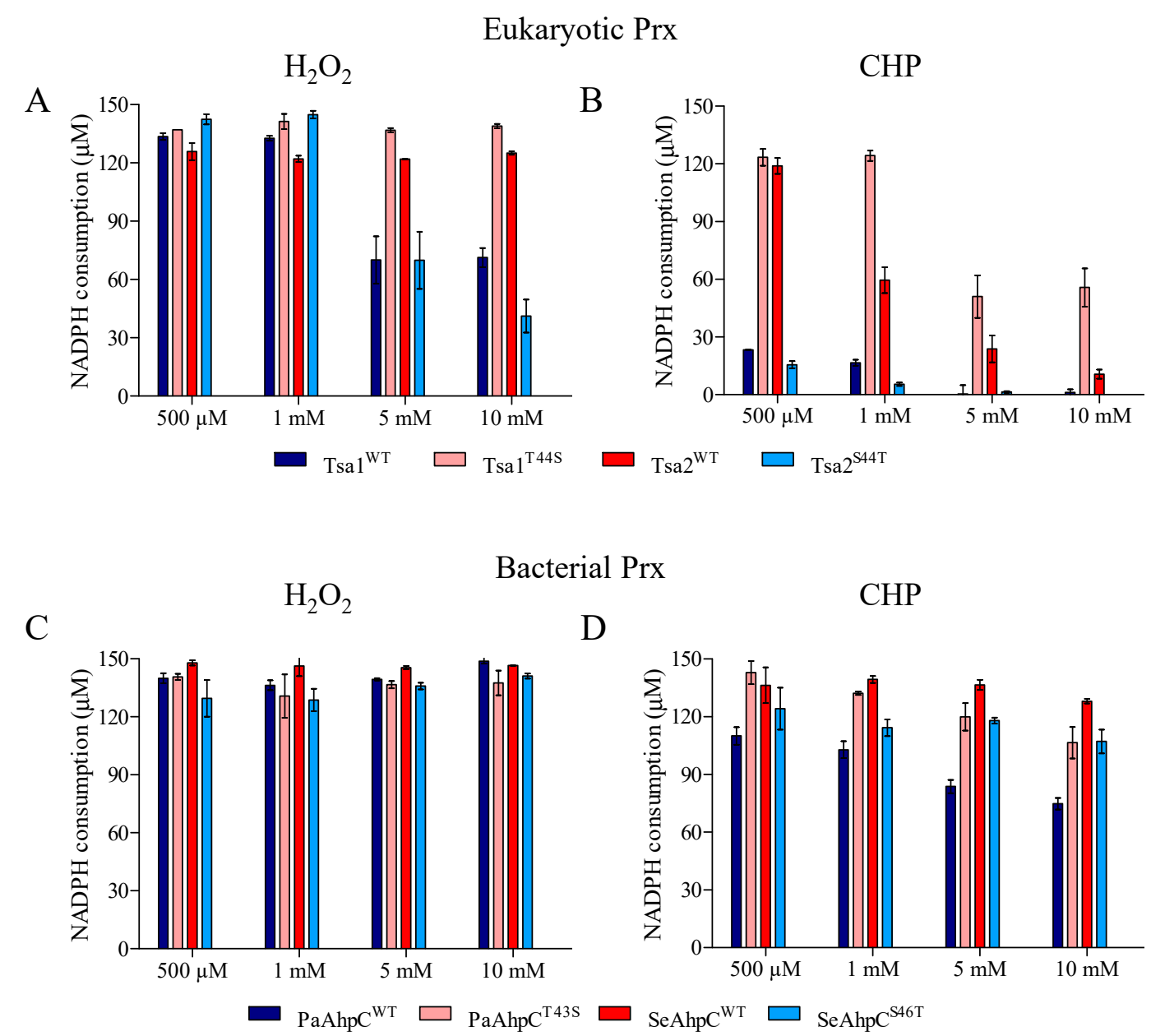

Figure 7. Evaluation of Thr-Prx and Ser-Prx inhibition. The amount of NADPH consumed after $300 \mathrm{~s}$ of reaction were obtained in the assays presented in Figure 2, Figure 3, and Figure 6, to $\mathrm{H}_{2} \mathrm{O}_{2}$ (A, eukaryotic Prx; C, bacterial Prx) and CHP (B, eukaryotic Prx; D, bacterial Prx). Comparing the values obtained to wild type with the reciprocal enzymes, it is possible to estimate which residue in catalytic triad makes the enzyme more resistant to hyperoxidation. Error bars represent the standard deviations.
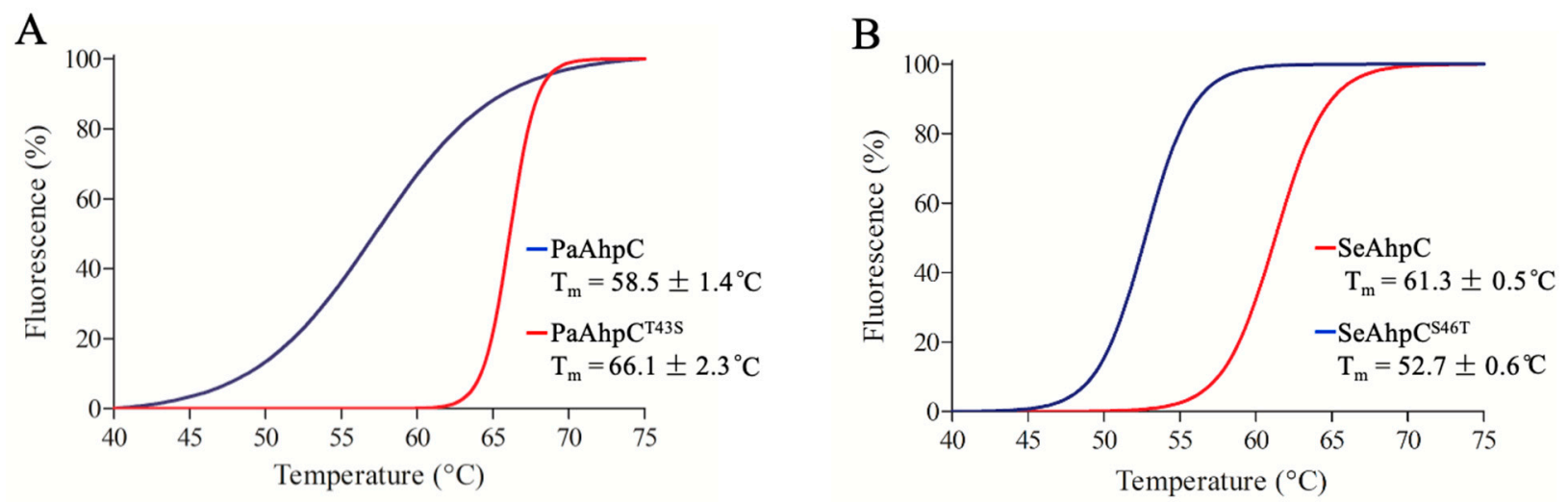

Figure 8. AhpC thermal unfolding monitored by DSF. Differential scanning fluorimetry of PaAhpC (A, blue line), $\operatorname{PaAhpC}^{\mathrm{T} 43 \mathrm{~S}}$ (A, red line), SeAhpC (B, red line), and SeAhpC ${ }^{\mathrm{S} 46 \mathrm{~T}}$ (B, blue line). Proteins were previously reduced with DTT (20 mM), desalted (PD10, GE Healthcare), and incubated with SYPRO Orange dye. The fluorescence scanning was carried out using a temperature gradient from $25^{\circ} \mathrm{C}$ to $95^{\circ} \mathrm{C}$. The melting temperature $\left(T_{\mathrm{m}}\right)$ was determined by the Boltzmann equation to determine the midpoint of thermal denaturation. The experiments were performed in triplicate and repeated at least three times with similar results. 

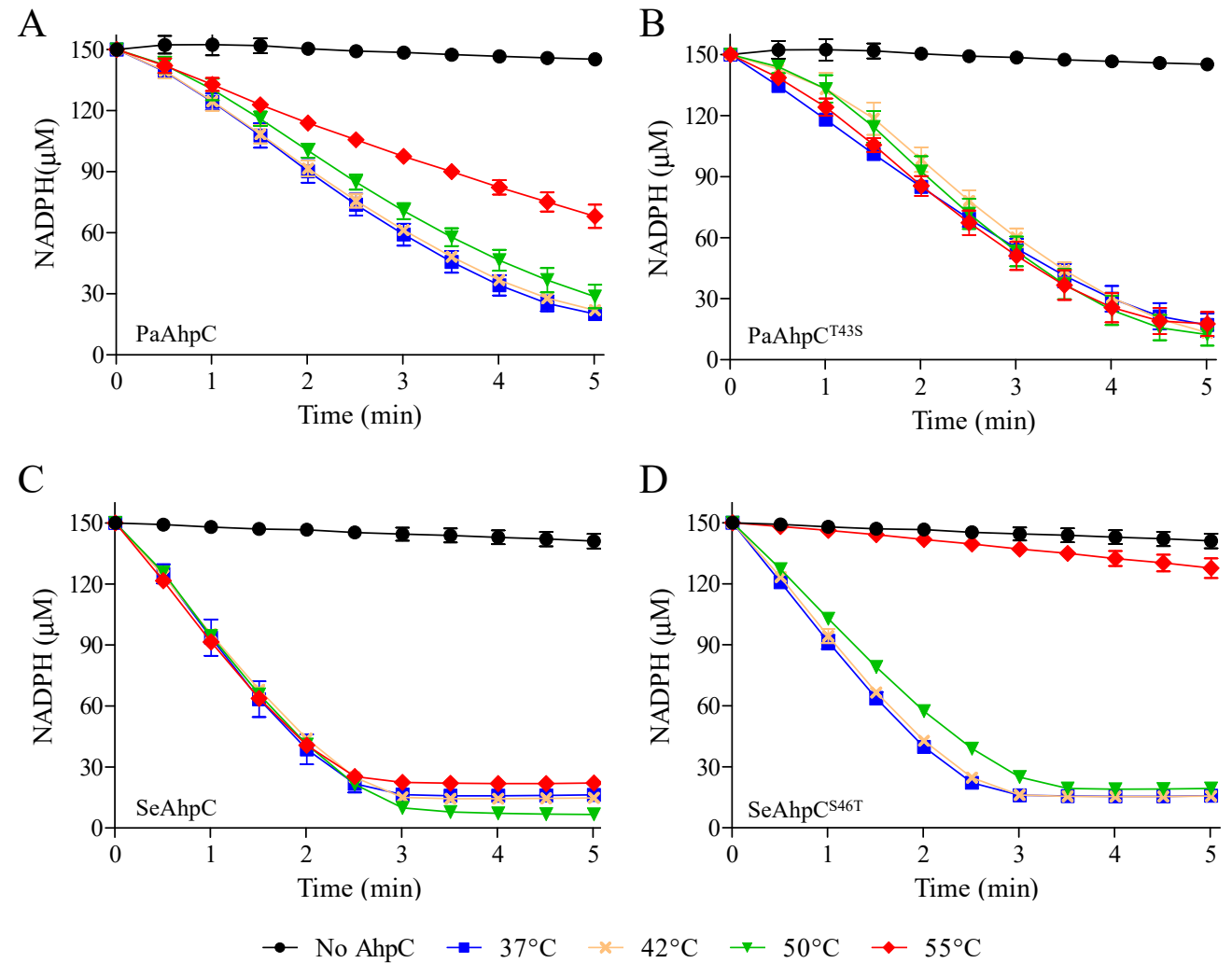

Figure 9. NADPH oxidation assay to assess the effects of thermal inactivation of AhpC enzymes. Aliquots of the $\operatorname{PaAhpC}(\mathbf{A}), \operatorname{PaAhpC}^{\mathrm{T} 43 \mathrm{~S}}$ (B), SeAhpC (C) and SeAhpC $\mathrm{C}^{\mathrm{S} 46 \mathrm{~T}}$ (D) were incubated at different temperatures $\left(37^{\circ} \mathrm{C}=\mathbf{\square}\right.$ blue, $42{ }^{\circ} \mathrm{C}=\times$ orange, $50{ }^{\circ} \mathrm{C}=\boldsymbol{\nabla}$ green and $55^{\circ} \mathrm{C}=\boldsymbol{\text { red}}$ ) for $1 \mathrm{~h}$. Then the enzymes were added to the reactions containing $6 \mu \mathrm{M}$ EcTrx, $0.9 \mu \mathrm{M}$ EcTrxR, $150 \mu \mathrm{M}$ NADPH, 50 mM HEPES (pH 7.0), $100 \mu \mathrm{M}$ DTPA, and 1mM sodium azide. The reactions were initiated by the addition of $500 \mu \mathrm{M} \mathrm{H}_{2} \mathrm{O}_{2}$ and absorbance at $340 \mathrm{~nm}$ was monitored at $37^{\circ} \mathrm{C}$, for $5 \mathrm{~min}$. As negative control $(\bullet$ black), reactions were performed without the addition of the AhpC. The standard deviations are represented by the error bars. All experiments were performed at least three times and yielded similar results using replicates.

\subsection{AhpC Containing Ser Presented Enhanced Chaperone Activity}

We also investigated the abilities of these AhpCs to protect citrate synthase (CS) against thermal insult. CS slowly aggregated when kept at $48{ }^{\circ} \mathrm{C}$ as indicated by increased light scattering as a function of time (Figure 10A,B, black lines). In the presence of PaAhpC, the CS aggregation decreased significantly (Figure 10A, blue line). We also tested if the pre-treatment of $\mathrm{PaAhpC}$ at $48^{\circ} \mathrm{C}$ by $1 \mathrm{~h}$ was able to exert additional protection to CS, but no difference was observed in comparison to the untreated enzyme (Figure 10A, red line). In the case of SeAhpC, the sample without thermal pre-treatment presented a more pronounced protection activity (Figure 10B, blue line) than PaAhpC. Notably, pre-heated SeAhpC $\left(48^{\circ} \mathrm{C} / 1 \mathrm{~h}\right)$ protected CS with very high efficiency, because only a negligible amount of CS aggregated (Figure 10B, red line). Therefore, our results suggest that AhpCs containing Ser in the catalytic triad are more prone to act as chaperone induced by heat shock stress than their counterparts containing Thr. 

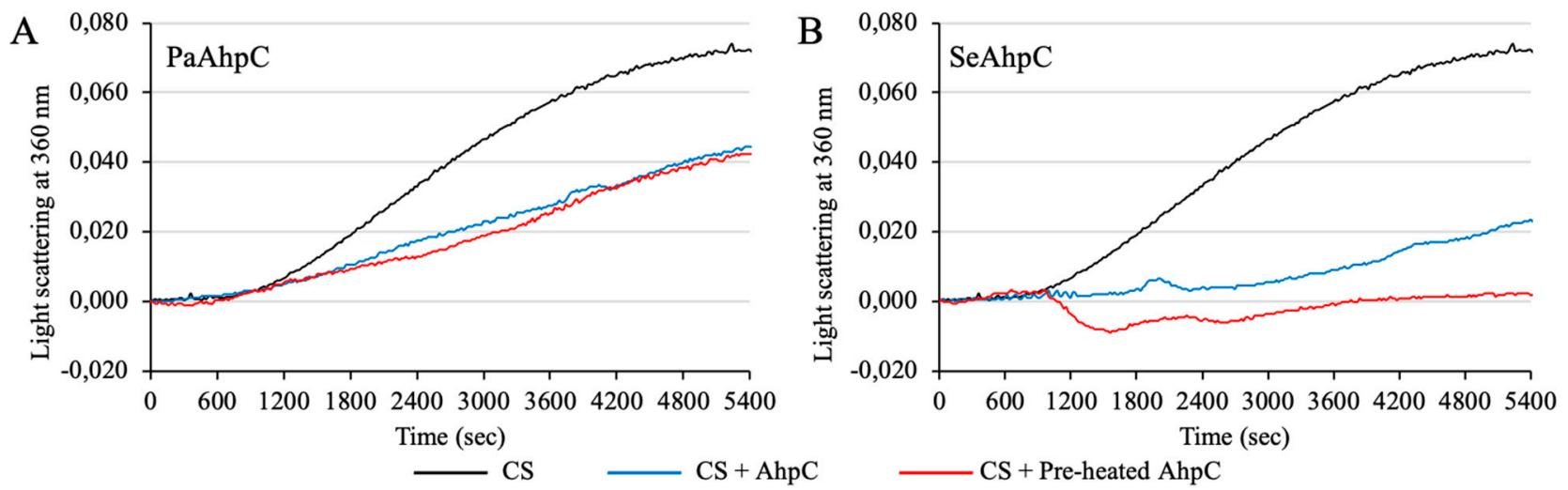

Figure 10. Comparative protection of PaAhpC and SeAhpC to citrate synthase (CS) aggregation by thermal stress. Chaperone activity of PaAhpC and SeAhpC was monitored by its ability to protect citrate synthase (CS) from thermally induced aggregation. The aggregation of $2 \mu \mathrm{M}$ of CS in $40 \mathrm{mM}$ HEPES-KOH pH 7.5 was monitored by light scattering $(\lambda=360 \mathrm{~nm})$ for $90 \mathrm{~min}$, either alone or in the presence of $40 \mu \mathrm{M}$ PaAhpC (A) or SeAhpC (B). The assays were executed with the enzyme pre-heated at $48^{\circ} \mathrm{C}$ for $1 \mathrm{~h}$ (red lines) or not (blue lines). The CS alone was used as negative control (black lines). The experiments were performed in triplicates under the same conditions.

The ability of the typical 2-Cys Prx to act as chaperone (holdase) was already described for several enzymes from eukaryotes [32,33] and from some bacterial proteins [34,62,63]. These enzymes are able to switch from peroxidase to chaperone in response to oxidative stress, by hyperoxidation of $C_{P}$ or by thermal stress. Considering the high resistance of AhpC to $C_{P}$ hyperoxidation, the thermal stress may be the main factor that triggers the chaperone activity, as observed by Kamariah and coworkers (2018) using E. coli AhpC (Thr-Prx) as model [34]. Here, we observed the same effect for SeAhpC, which is a Ser-Prx. It is tempting to speculate that chaperone activity may be facilitated in these enzymes because they are stabilized as decamers, irrespective to the oxidative state.

\section{Discussion}

The roles of Thr or Ser in the catalytic triad of the typical 2-Cys Prx has been considered redundant, but recently, we (and others) showed that Ser-Prx are more stable in the decameric form [3,49]. Here, we demonstrated that the presence of Ser or Thr in the active site affected also the $C_{P}$ hyperoxidation susceptibilities, especially for yeast 2-Cys Prx, besides being related to thermal resistance and the chaperone activities acquisition of AhpCs. Furthermore, we showed that the vast majority of multicellular organisms have Thr on catalytic triad. Ser-Prx is more prevalent in bacteria, which might be related with diverse ecological strategies in some groups of this domain. Although the typical 2-Cys Prx from bacteria are very resistant to hyperoxidation, we demonstrated that the Thr to Ser substitution slightly increased the resistance to inactivation of AhpC by CHP.

Previously, eukaryotic 2-Cys Prx were described to be highly susceptible to oxidative inactivation in comparison with bacterial counterparts [40]. Accordingly, eukaryotic 2-Cys Prx were named as sensitive, while bacterial enzymes were referred as robust. Furthermore, authors identified the presence of GGLG and YF motifs exclusively in eukaryotic 2-Cys Prx, which were proposed to be positively selected during evolution [40]. The presence of the GGLG and YF motifs near the $C_{P}$ residue would represent a steric hindrance effect, decreasing the rate of intermolecular disulfide bond formation [37]. According to this model, $\mathrm{C}_{\mathrm{R}}$ and $\mathrm{H}_{2} \mathrm{O}_{2}$ compete for $\mathrm{C}_{\mathrm{P}}-\mathrm{SOH}$. Therefore, enzymes with fast rates of condensation reaction between $\mathrm{C}_{\mathrm{R}}$ and $\mathrm{C}_{\mathrm{P}}-\mathrm{SOH}$ would correspond to increased resistance to hyperoxidation. More recently, two other structural elements, named motifs A and B, were identified by conferring resistance to hyperoxidation in 2-Cys Prx [50].

Here, we analyzed the susceptibilities to hyperoxidation of sensitive (Tsa1, Tsa2) and robust (PaAhpC, SeAhpC) 2-Cys Prx carrying Thr or Ser in the catalytic triad. Remarkably, yeast Ser-Prx (Tsa1 ${ }^{\mathrm{T} 44 \mathrm{~S}}$ and Tsa2) are considerably more resistant to inactivation than Thr- 
$\operatorname{Prx}\left(\right.$ Tsa 1 and Tsa $2^{\mathrm{S} 44 \mathrm{~T}}$ ) by hyperoxidation (Figure 2, Figure 3, and Figure 7) and this effect is only moderate in bacterial enzymes treated with CHP (Figures 6 and 7). Noteworthy, motifs A and B previously described as resistance factors to hyperoxidation [50] are also highly similar among the yeast and bacterial counterparts (Supplementary material, Table S1 and Figure S3). Therefore, the observed differences in inactivation between Tsa1 and Tsa2 or between PaAhpC and SeAhpC are probably not related to the compositions of motifs A and $B$ in these enzymes. In fact, the natural substitution of catalytic triad Thr to Ser stands as a novel trait related to resistance or susceptibility to $C_{P}$ hyperoxidation.

We also analyzed the crystallographic structures of Tsa1 $(\mathrm{PDB}=3 \mathrm{SBC})$ and Tsa2 $(\mathrm{PDB}=5 \mathrm{DVB})$ to gain insights on mechanisms underlying differences in the hyperoxidation susceptibilities. In our previous work [3], we observed that the side chain of catalytic Ser presents higher mobility than the Thr in Tsa1. The additional methyl group in Thr side chain interacts with an aromatic ring in the adjacent dimer. Thus, the B-factor of active site regions in the 10 chains of Tsa2 structure are higher than observed to Tsa1. Now, we analyzed the interactions of catalytic Thr and Ser in an attempt to explain the differences in hyperoxidation resistance. We observed that the $\mathrm{Ser}^{44}$ in some chains of Tsa2 are in position quite similar to $\mathrm{Thr}^{44}$ in Tsa1 (Figure 11A). However, in three chains, the Ser ${ }^{44}$ of Tsa2 are found in an alternative position compared to that one observed to $\mathrm{Thr}^{44}$. Consequently, the motif GGLG is moved away from the C-terminal $\alpha$-helix where YF motif is found (Figure 11B) and a helix upstream to the GGLG motif is also deformed. We propose that the high mobility of Ser side chain makes the interaction between GGLG and C-terminal motif YF more unstable and, therefore, facilitate the approximation between $C_{P}$ and $C_{R}$ and disulfide formation. In fact, our data indicated that, in yeast enzymes (displaying the GGLG/YF motifs), the differences in hyperoxidation are more pronounced between Ser-Prx and Thr-Prx. Accordingly, Peskin and colleagues (2021) [61] showed that substitution of human Prx2 $C_{R}$ by amino acids that disrupts the C-terminal structure is able to affect the enzyme activity, indicating an interconnection between the $\mathrm{C}$-terminal region and the active site microenvironment in eukaryotes. These data indicate that even regions located far from the active site can exert effect in the 2-Cys Prx activity.
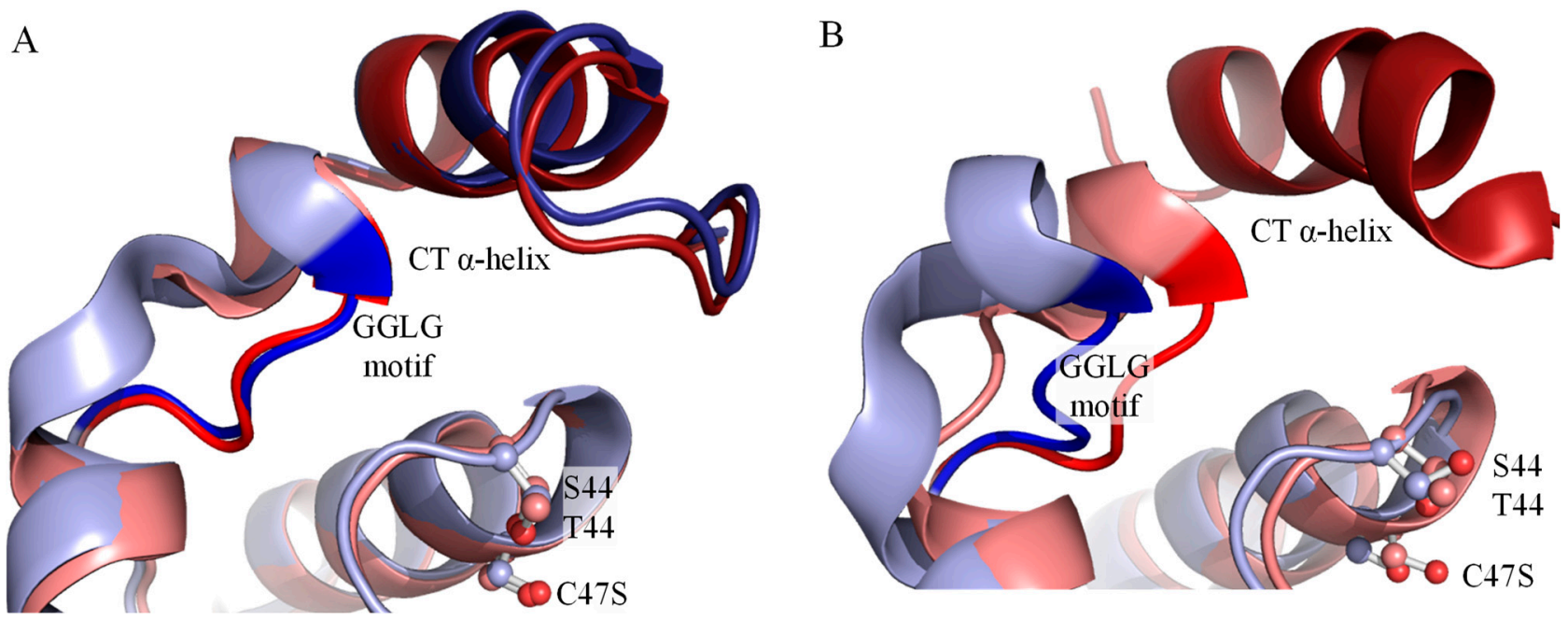

Figure 11. Active site, GGLG and YF motif regions of Tsa1 and Tsa2. (A) Superposition of Tsa1 ${ }^{\mathrm{C} 47 \mathrm{~S}}$ (3SBC = pink) and Tsa2 ${ }^{C 47 S}$ (5DVB = light blue) show similar position of Thr $^{44}$ (Tsa1) and Ser ${ }^{44}$ (Tsa2). Motif GGLG (red in Tsa1 and blue in Tsa2) and CT $\alpha$-helix (dark red in Tsa1 and dark blue in Tsa2) are also in quite similar position. (B) When Ser ${ }^{44}$ is found in an alternative conformation, GGLG motif is displaced to a further position, while CT $\alpha$-helix do not appear in the crystallographic structure probably due to being more mobile and, consequently, with low resolution. Crystallographic structures are presented in cartoon and highlighted amino acids are presented as balls and sticks. Graphical models were generated by PyMOL. 
In contrast, Thr/Ser substitutions in PaAhpC and SeAhpC produce less pronounced effects on the susceptibilities to hyperoxidation, possibly due to GGLG and YF motifs are absent at these enzymes. We compared the crystallographic structure of a Thr-Prx (Salmonella typhimurium AhpC-PDB entry 1YEP) with the only AhpC containing Ser in the PDB database (Enterococcus faecalis-PDB entry 5Y63), but we did not observe any major structural differences. However, it is worth to mention that disulfide formation in bacterial AhpC belonging to Thr-Prx group is considerable faster $\left(75 \mathrm{~s}^{-1}\right)$ compared to human enzymes such as Prx2 and Prx3 (1.7 and $22 \mathrm{~s}^{-1}$, respectively) [38,64].

We also observed that 2-Cys Prx are more susceptible to hyperoxidation by organic hydroperoxides than $\mathrm{H}_{2} \mathrm{O}_{2}$ (Figures 2, 3 and 6), as previously described [34], which may be related with the environment close to the active site pocket. Crystallographic observations revealed the presence of large hydrophobic portions around this region [40,43,48]. In fact, $a h p c$ gene inactivation frequently render bacteria with increased sensitivity to organic peroxide and AhpC over-expression invariably leads to a gain of resistance against these oxidants [65-71]. Moreover, Mycobacterium tuberculosis and Helicobacter pylori mutants for ahpc gene accumulated higher levels of lipid hydroperoxides during aerobic growth, when compared to wild type strains [72].

Considering that presence of Ser in catalytic triad makes 2-Cys Prx resistant to $C_{P}$ hyperoxidation, more stable as a decamer and increase its chaperone activity, we speculate that these enzymes may present complementary functions, protecting cells from severe stressful conditions. Ser-Prx might be more prone to hydroperoxides detoxification and thermal stress defense, while Thr-Prx would be better adapted to cell signaling functions. Notably, Ser-Prx were able to perform both peroxidase and chaperone activities after heat shock and possibly these molecular activities may occur simultaneously. Consistent with this idea, Ser-Prx are more frequent in bacteria, some of them pathogenic. Therefore, SerPrx might be considered as target for the development of specific inhibitors to prokaryotic enzymes. Finally, it is amazing to note that a single residue substitution by another with similar properties can confer remarkable functional and structural differences between very homologous enzymes.

\section{Conclusions}

The single natural substitution of the active site catalytic triad Thr to Ser occurs in several 2-Cys Prx from different organisms and influences the oligomeric redox state, resistance to hyperoxidation, thermostability, and chaperone activity defining two groups among the 2-Cys Prx: Ser-Prx and Thr-Prx. This substitution may have been selected during the evolutive process and can be directly related to differential functions of these enzymes in the cells.

Supplementary Materials: The following are available online at https:/ /www.mdpi.com/article/10 .3390/antiox10071032/s1, Figure S1: Western blot to confirm CP hyperoxidation of Tsa1 and Tsa2; Figure S2: Evaluation of AhpC hyperoxidation by western blotting; Figure S3: Sequence alignment of Tsa1, Tsa2 and bacterial typical 2-Cys Prx to evaluate the conservation of the hyperoxidation resistance motifs (named A and B) and catalytic triad Thr or Ser distribution; Spreadsheet S1: Distribution of typical 2-Cys Prx among the organisms; Table S1: Conservation of hyperoxidation resistance motifs in typical 2-Cys peroxiredoxins isoforms.

Author Contributions: Conceptualization, M.A.d.O., L.E.S.N., C.A.B., M.C.S. and C.A.T.; methodology, M.A.d.O., L.E.S.N., C.A.B., M.C.S. and C.A.T.; formal analysis, M.A.d.O., L.E.S.N., M.H.T., C.A.B., A.L.P.d.O., M.C.S., G.M.M., G.T.-S. and C.A.T.; investigation, C.A.B., M.C.S., A.L.P.d.O., G.M.M., G.T.-S., V.I.M.C. and C.A.T.; writing-original draft preparation, M.C.S., C.A.T., L.E.S.N. and M.A.d.O. All authors have read and agreed to the published version of the manuscript. 
Funding: The authors M.A.d.O., M.C.S., A.L.P.d.O., C.A.T., and L.E.S.N. are members of the CEPID REDOXOMA from the Fundação de Amparo à Pesquisa do Estado de São Paulo (FAPESP) (grant number 2013/07937-8). This work was also supported by grants from FAPESP to M.A.O. (2007/509303; 2017/19942-7) and M.H.T. (2017/20291-0). C.A.B., M.C.S., C.A.T, A.L.P.d.O., and V.I.M.C. were recipients of fellowships from FAPESP (2011/13500-6; 2017/06263-4; 2018/12628-8; 2019/04054-4; and 2020/02868-1).

Institutional Review Board Statement: Not applicable.

Informed Consent Statement: Not applicable.

Data Availability Statement: The sequence of the S. epidermidis ahpc synthetic gene with the codons optimized for expression in E. coli is available at NCBI GenBank (accession code MZ133620).

Conflicts of Interest: The authors declare that the research was conducted in the absence of any commercial or financial relationships that could be considered a conflict of interest.

\section{References}

1. Horta, B.B.; de Oliveira, M.A.; Discola, K.F.; Cussiol, J.R.; Netto, L.E. Structural and biochemical characterization of peroxiredoxin Qbeta from Xylella fastidiosa: Catalytic mechanism and high reactivity. J. Biol. Chem. 2010, 285, 16051-16065. [CrossRef] [PubMed]

2. Ogusucu, R.; Rettori, D.; Munhoz, D.C.; Netto, L.E.; Augusto, O. Reactions of yeast thioredoxin peroxidases I and II with hydrogen peroxide and peroxynitrite: Rate constants by competitive kinetics. Free Radic. Biol. Med. 2007, 42, 326-334. [CrossRef] [PubMed]

3. Tairum, C.A.; Santos, M.C.; Breyer, C.A.; Geyer, R.R.; Nieves, C.J.; Portillo-Ledesma, S.; Ferrer-Sueta, G.; Toledo, J.C., Jr.; Toyama, M.H.; Augusto, O.; et al. Catalytic Thr or Ser Residue Modulates Structural Switches in 2-Cys Peroxiredoxin by Distinct Mechanisms. Sci. Rep. 2016, 6, 33133. [CrossRef]

4. Truzzi, D.R.; Coelho, F.R.; Paviani, V.; Alves, S.V.; Netto, L.E.S.; Augusto, O. The bicarbonate/carbon dioxide pair increases hydrogen peroxide-mediated hyperoxidation of human peroxiredoxin 1. J. Biol. Chem. 2019, 294, 14055-14067. [CrossRef] [PubMed]

5. Bengtsson-Palme, J.; Alm Rosenblad, M.; Molin, M.; Blomberg, A. Metagenomics reveals that detoxification systems are underrepresented in marine bacterial communities. BMC Genom. 2014, 15, 749. [CrossRef]

6. Chae, H.Z.; Kim, H.J.; Kang, S.W.; Rhee, S.G. Characterization of three isoforms of mammalian peroxiredoxin that reduce peroxides in the presence of thioredoxin. Diabetes Res. Clin. Pract. 1999, 45, 101-112. [CrossRef]

7. Ghaemmaghami, S.; Huh, W.K.; Bower, K.; Howson, R.W.; Belle, A.; Dephoure, N.; O'Shea, E.K.; Weissman, J.S. Global analysis of protein expression in yeast. Nature 2003, 425, 737-741. [CrossRef]

8. Wood, Z.A.; Schroder, E.; Robin Harris, J.; Poole, L.B. Structure, mechanism and regulation of peroxiredoxins. Trends Biochem. Sci. 2003, 28, 32-40. [CrossRef]

9. Cox, A.G.; Winterbourn, C.C.; Hampton, M.B. Mitochondrial peroxiredoxin involvement in antioxidant defence and redox signalling. Biochem. J. 2009, 425, 313-325. [CrossRef]

10. Winterbourn, C.C. Reconciling the chemistry and biology of reactive oxygen species. Nat. Chem. Biol. 2008, 4, 278-286. [CrossRef]

11. Brown, J.D.; Day, A.M.; Taylor, S.R.; Tomalin, L.E.; Morgan, B.A.; Veal, E.A. A peroxiredoxin promotes H2O2 signaling and oxidative stress resistance by oxidizing a thioredoxin family protein. Cell Rep. 2013, 5, 1425-1435. [CrossRef]

12. Netto, L.E.; Antunes, F. The Roles of Peroxiredoxin and Thioredoxin in Hydrogen Peroxide Sensing and in Signal Transduction. Mol. Cells 2016, 39, 65-71.

13. Rhee, S.G.; Woo, H.A. Multiple functions of peroxiredoxins: Peroxidases, sensors and regulators of the intracellular messenger $\mathrm{H}(2) \mathrm{O}(2)$, and protein chaperones. Antioxid. Redox Signal. 2011, 15, 781-794. [CrossRef] [PubMed]

14. Stocker, S.; Maurer, M.; Ruppert, T.; Dick, T.P. A role for 2-Cys peroxiredoxins in facilitating cytosolic protein thiol oxidation. Nat. Chem. Biol. 2018, 14, 148-155. [CrossRef] [PubMed]

15. Tang, H.M.; Siu, K.L.; Wong, C.M.; Jin, D.Y. Loss of yeast peroxiredoxin Tsa1p induces genome instability through activation of the DNA damage checkpoint and elevation of dNTP levels. PLoS Genet. 2009, 5, e1000697. [CrossRef]

16. Chae, H.Z.; Chung, S.J.; Rhee, S.G. Thioredoxin-dependent peroxide reductase from yeast. J. Biol. Chem. 1994, 269, 27670-27678. [CrossRef]

17. Jonsson, T.J.; Ellis, H.R.; Poole, L.B. Cysteine reactivity and thiol-disulfide interchange pathways in AhpF and AhpC of the bacterial alkyl hydroperoxide reductase system. Biochemistry 2007, 46, 5709-5721. [CrossRef] [PubMed]

18. Netto, L.E.S.; Chae, H.Z.; Kang, S.W.; Rhee, S.G.; Stadtman, E.R. Removal of hydrogen peroxide by thiol-specific antioxidant enzyme (TSA) is involved with its antioxidant properties. TSA possesses thiol peroxidase activity. J. Biol. Chem. 1996, 271, 15315-15321. [CrossRef] [PubMed]

19. Pineyro, M.D.; Arcari, T.; Robello, C.; Radi, R.; Trujillo, M. Tryparedoxin peroxidases from Trypanosoma cruzi: High efficiency in the catalytic elimination of hydrogen peroxide and peroxynitrite. Arch. Biochem. Biophys. 2011, 507, 287-295. [CrossRef] [PubMed]

20. Hall, A.; Parsonage, D.; Poole, L.B.; Karplus, P.A. Structural evidence that peroxiredoxin catalytic power is based on transitionstate stabilization. J. Mol. Biol. 2010, 402, 194-209. [CrossRef] 
21. Chae, H.Z.; Kim, I.H.; Kim, K.; Rhee, S.G. Cloning, sequencing, and mutation of thiol-specific antioxidant gene of Saccharomyces cerevisiae. J. Biol. Chem. 1993, 268, 16815-16821. [CrossRef]

22. Flohe, L.; Budde, H.; Bruns, K.; Castro, H.; Clos, J.; Hofmann, B.; Kansal-Kalavar, S.; Krumme, D.; Menge, U.; Plank-Schumacher, K.; et al. Tryparedoxin peroxidase of Leishmania donovani: Molecular cloning, heterologous expression, specificity, and catalytic mechanism. Arch. Biochem. Biophys. 2002, 397, 324-335. [CrossRef] [PubMed]

23. Konig, J.; Lotte, K.; Plessow, R.; Brockhinke, A.; Baier, M.; Dietz, K.J. Reaction mechanism of plant 2-Cys peroxiredoxin. Role of the $C$ terminus and the quaternary structure. J. Biol. Chem. 2003, 278, 24409-24420. [CrossRef] [PubMed]

24. Miranda-Vizuete, A.; Damdimopoulos, A.E.; Pedrajas, J.R.; Gustafsson, J.A.; Spyrou, G. Human mitochondrial thioredoxin reductase cDNA cloning, expression and genomic organization. Eur. J. Biochem. 1999, 261, 405-412. [CrossRef]

25. Nagy, P.; Karton, A.; Betz, A.; Peskin, A.V.; Pace, P.; O’Reilly, R.J.; Hampton, M.B.; Radom, L.; Winterbourn, C.C. Model for the exceptional reactivity of peroxiredoxins 2 and 3 with hydrogen peroxide: A kinetic and computational study. J. Biol. Chem. 2011, 286, 18048-18055. [CrossRef] [PubMed]

26. Portillo-Ledesma, S.; Sardi, F.; Manta, B.; Tourn, M.V.; Clippe, A.; Knoops, B.; Alvarez, B.; Coitino, E.L.; Ferrer-Sueta, G. Deconstructing the catalytic efficiency of peroxiredoxin-5 peroxidatic cysteine. Biochemistry 2014, 53, 6113-6125. [CrossRef]

27. Biteau, B.; Labarre, J.; Toledano, M.B. ATP-dependent reduction of cysteine-sulphinic acid by S. cerevisiae sulphiredoxin. Nature 2003, 425, 980-984. [CrossRef]

28. Jonsson, T.J.; Johnson, L.C.; Lowther, W.T. Structure of the sulphiredoxin-peroxiredoxin complex reveals an essential repair embrace. Nature 2008, 451, 98-101. [CrossRef]

29. Day, A.M.; Brown, J.D.; Taylor, S.R.; Rand, J.D.; Morgan, B.A.; Veal, E.A. Inactivation of a peroxiredoxin by hydrogen peroxide is critical for thioredoxin-mediated repair of oxidized proteins and cell survival. Mol. Cell 2012, 45, 398-408. [CrossRef]

30. Del Olmo, M.; Kramer, A.; Herzel, H. A Robust Model for Circadian Redox Oscillations. Int. J. Mol. Sci. 2019, 20, 2368. [CrossRef]

31. Edgar, R.S.; Green, E.W.; Zhao, Y.; van Ooijen, G.; Olmedo, M.; Qin, X.; Xu, Y.; Pan, M.; Valekunja, U.K.; Feeney, K.A.; et al. Peroxiredoxins are conserved markers of circadian rhythms. Nature 2012, 485, 459-464. [CrossRef] [PubMed]

32. Veal, E.A.; Underwood, Z.E.; Tomalin, L.E.; Morgan, B.A.; Pillay, C.S. Hyperoxidation of Peroxiredoxins: Gain or Loss of Function? Antioxid. Redox Signal. 2018, 28, 574-590. [CrossRef] [PubMed]

33. Jang, H.H.; Lee, K.O.; Chi, Y.H.; Jung, B.G.; Park, S.K.; Park, J.H.; Lee, J.R.; Lee, S.S.; Moon, J.C.; Yun, J.W.; et al. Two enzymes in one; two yeast peroxiredoxins display oxidative stress-dependent switching from a peroxidase to a molecular chaperone function. Cell 2004, 117, 625-635. [CrossRef] [PubMed]

34. Kamariah, N.; Eisenhaber, B.; Eisenhaber, F.; Gruber, G. Molecular mechanism of the Escherichia coli AhpC in the function of a chaperone under heat-shock conditions. Sci. Rep. 2018, 8, 14151. [CrossRef]

35. Moon, J.C.; Hah, Y.S.; Kim, W.Y.; Jung, B.G.; Jang, H.H.; Lee, J.R.; Kim, S.Y.; Lee, Y.M.; Jeon, M.G.; Kim, C.W.; et al. Oxidative stress-dependent structural and functional switching of a human 2-Cys peroxiredoxin isotype II that enhances HeLa cell resistance to H2O2-induced cell death. J. Biol. Chem. 2005, 280, 28775-28784. [CrossRef]

36. Teixeira, F.; Tse, E.; Castro, H.; Makepeace, K.A.T.; Meinen, B.A.; Borchers, C.H.; Poole, L.B.; Bardwell, J.C.; Tomas, A.M.; Southworth, D.R.; et al. Chaperone activation and client binding of a 2-cysteine peroxiredoxin. Nat. Commun. 2019, 10, 659. [CrossRef]

37. Hall, A.; Nelson, K.; Poole, L.B.; Karplus, P.A. Structure-based insights into the catalytic power and conformational dexterity of peroxiredoxins. Antioxid. Redox Signal. 2011, 15, 795-815. [CrossRef]

38. Peskin, A.V.; Dickerhof, N.; Poynton, R.A.; Paton, L.N.; Pace, P.E.; Hampton, M.B.; Winterbourn, C.C. Hyperoxidation of peroxiredoxins 2 and 3: Rate constants for the reactions of the sulfenic acid of the peroxidatic cysteine. J. Biol. Chem. 2013, 288, 14170-14177. [CrossRef]

39. Wood, Z.A.; Poole, L.B.; Hantgan, R.R.; Karplus, P.A. Dimers to doughnuts: Redox-sensitive oligomerization of 2-cysteine peroxiredoxins. Biochemistry 2002, 41, 5493-5504. [CrossRef]

40. Wood, Z.A.; Poole, L.B.; Karplus, P.A. Peroxiredoxin evolution and the regulation of hydrogen peroxide signaling. Science 2003, 300, 650-653. [CrossRef]

41. Angelucci, F.; Saccoccia, F.; Ardini, M.; Boumis, G.; Brunori, M.; Di Leandro, L.; Ippoliti, R.; Miele, A.E.; Natoli, G.; Scotti, S.; et al. Switching between the alternative structures and functions of a 2-Cys peroxiredoxin, by site-directed mutagenesis. J. Mol. Biol. 2013, 425, 4556-4568. [CrossRef]

42. Pastor-Flores, D.; Talwar, D.; Pedre, B.; Dick, T.P. Real-time monitoring of peroxiredoxin oligomerization dynamics in living cells. Proc. Natl. Acad. Sci. USA 2020, 117, 16313-16323. [CrossRef]

43. Dip, P.V.; Kamariah, N.; Nartey, W.; Beushausen, C.; Kostyuchenko, V.A.; Ng, T.S.; Lok, S.M.; Saw, W.G.; Eisenhaber, F.; Eisenhaber, B.; et al. Key roles of the Escherichia coli AhpC C-terminus in assembly and catalysis of alkylhydroperoxide reductase, an enzyme essential for the alleviation of oxidative stress. Biochim. Biophys. Acta 2014, 1837, 1932-1943. [CrossRef]

44. Barranco-Medina, S.; Dietz, K.J. Thermodynamics of 2-Cys peroxiredoxin assembly determined by isothermal titration calorimetry. Methods Enzymol. 2009, 466, 409-430.

45. Liebthal, M.; Kushwah, M.S.; Kukura, P.; Dietz, K.J. Single molecule mass photometry reveals dynamic oligomerization of plant and human peroxiredoxins for functional conservation and diversification. bioRxiv 2021. [CrossRef] 
46. Morais, M.A.; Giuseppe, P.O.; Souza, T.A.; Alegria, T.G.; Oliveira, M.A.; Netto, L.E.; Murakami, M.T. How pH modulates the dimer-decamer interconversion of 2-Cys peroxiredoxins from the Prx1 subfamily. J. Biol. Chem. 2015, 290, 8582-8590. [CrossRef] [PubMed]

47. Morais, M.A.B.; Giuseppe, P.O.; Souza, T.; Castro, H.; Honorato, R.V.; Oliveira, P.S.L.; Netto, L.E.S.; Tomas, A.M.; Murakami, M.T. Calcium and magnesium ions modulate the oligomeric state and function of mitochondrial 2-Cys peroxiredoxins in Leishmania parasites. J. Biol. Chem. 2017, 292, 7023-7039. [CrossRef] [PubMed]

48. Pan, A.; Balakrishna, A.M.; Nartey, W.; Kohlmeier, A.; Dip, P.V.; Bhushan, S.; Gruber, G. Atomic structure and enzymatic insights into the vancomycin-resistant Enterococcus faecalis (V583) alkylhydroperoxide reductase subunit C. Free Radic. Biol. Med. 2018, 115, 252-265. [CrossRef] [PubMed]

49. Nelson, K.J.; Perkins, A.; Van Swearingen, A.E.D.; Hartman, S.; Brereton, A.E.; Parsonage, D.; Salsbury, F.R., Jr.; Karplus, P.A.; Poole, L.B. Experimentally Dissecting the Origins of Peroxiredoxin Catalysis. Antioxid. Redox Signal. 2018, 28, 521-536. [CrossRef] [PubMed]

50. Bolduc, J.A.; Nelson, K.J.; Haynes, A.C.; Lee, J.; Reisz, J.A.; Graff, A.H.; Clodfelter, J.E.; Parsonage, D.; Poole, L.B.; Furdui, C.M.; et al. Novel hyperoxidation resistance motifs in 2-Cys peroxiredoxins. J. Biol. Chem. 2018, 293, 11901-11912. [CrossRef] [PubMed]

51. Oliveira, M.A.; Discola, K.F.; Alves, S.V.; Medrano, F.J.; Guimaraes, B.G.; Netto, L.E. Insights into the specificity of thioredoxin reductase-thioredoxin interactions. A structural and functional investigation of the yeast thioredoxin system. Biochemistry 2010, 49, 3317-3326. [CrossRef]

52. Tairum, C.A., Jr.; de Oliveira, M.A.; Horta, B.B.; Zara, F.J.; Netto, L.E. Disulfide biochemistry in 2-cys peroxiredoxin: Requirement of Glu50 and Arg146 for the reduction of yeast Tsa1 by thioredoxin. J. Mol. Biol. 2012, 424, 28-41. [CrossRef]

53. Gonzalez Porque, P.; Baldesten, A.; Reichard, P. Purification of a thioredoxin system from yeast. J. Biol. Chem. 1970, $245,2363-2370$. [CrossRef]

54. Altschul, S.F.; Gish, W.; Miller, W.; Myers, E.W.; Lipman, D.J. Basic local alignment search tool. J. Mol. Biol. 1990, 215 , 403-410. [CrossRef]

55. Mistry, J.; Finn, R.D.; Eddy, S.R.; Bateman, A.; Punta, M. Challenges in homology search: HMMER3 and convergent evolution of coiled-coil regions. Nucleic Acids Res. 2013, 41, e121. [CrossRef] [PubMed]

56. Hofmann, B.; Hecht, H.J.; Flohe, L. Peroxiredoxins. Biol. Chem. 2002, 383, 347-364. [CrossRef] [PubMed]

57. Huynh, K.; Partch, C.L. Analysis of protein stability and ligand interactions by thermal shift assay. Curr. Protoc. Protein Sci. 2015, 79, 21-28. [CrossRef]

58. Kriznik, A.; Libiad, M.; Le Cordier, H.; Boukhenouna, S.; Toledano, M.B.; Rahuel-Clermont, S. Dynamics of a Key Conformational Transition in the Mechanism of Peroxiredoxin Sulfinylation. ACS Catal. 2020, 10, 3326-3339. [CrossRef]

59. Munhoz, D.C.; Netto, L.E. Cytosolic thioredoxin peroxidase I and II are important defenses of yeast against organic hydroperoxide insult: Catalases and peroxiredoxins cooperate in the decomposition of $\mathrm{H} 2 \mathrm{O} 2$ by yeast. J. Biol. Chem. 2004, 279, 35219-35227. [CrossRef]

60. Zwick, J.V.; Noble, S.; Ellaicy, Y.K.; Coe, G.D.; Hakey, D.J.; King, A.N.; Sadauskas, A.J.; Faulkner, M.J. AhpA is a peroxidase expressed during biofilm formation in Bacillus subtilis. Microbiologyopen 2017, 6, e00403. [CrossRef]

61. Peskin, A.V.; Meotti, F.C.; Kean, K.M.; Gobl, C.; Peixoto, A.S.; Pace, P.E.; Horne, C.R.; Heath, S.G.; Crowther, J.M.; Dobson, R.C.J.; et al. Modifying the resolving cysteine affects the structure and hydrogen peroxide reactivity of peroxiredoxin 2. J. Biol. Chem. 2021, in press. [CrossRef]

62. Chuang, M.H.; Wu, M.S.; Lo, W.L.; Lin, J.T.; Wong, C.H.; Chiou, S.H. The antioxidant protein alkylhydroperoxide reductase of Helicobacter pylori switches from a peroxide reductase to a molecular chaperone function. Proc. Natl. Acad. Sci. USA 2006, 103, 2552-2557. [CrossRef]

63. Lee, J.T.; Lee, S.S.; Mondal, S.; Tripathi, B.N.; Kim, S.; Lee, K.W.; Hong, S.H.; Bai, H.W.; Cho, J.Y.; Chung, B.Y. Enhancement of the Chaperone Activity of Alkyl Hydroperoxide Reductase C from Pseudomonas aeruginosa PAO1 Resulting from a Point-Specific Mutation Confers Heat Tolerance in Escherichia coli. Mol. Cells 2016, 39, 594-602. [CrossRef]

64. Parsonage, D.; Nelson, K.J.; Ferrer-Sueta, G.; Alley, S.; Karplus, P.A.; Furdui, C.M.; Poole, L.B. Dissecting peroxiredoxin catalysis: Separating binding, peroxidation, and resolution for a bacterial AhpC. Biochemistry 2015, 54, 1567-1575. [CrossRef]

65. Cha, M.K.; Bae, Y.J.; Kim, K.J.; Park, B.J.; Kim, I.H. Characterization of two alkyl hydroperoxide reductase C homologs alkyl hydroperoxide reductase C_H1 and alkyl hydroperoxide reductase C_H2 in Bacillus subtilis. World J. Biol. Chem. 2015, 6, 249-264. [CrossRef] [PubMed]

66. Charoenlap, N.; Eiamphungporn, W.; Chauvatcharin, N.; Utamapongchai, S.; Vattanaviboon, P.; Mongkolsuk, S. OxyR mediated compensatory expression between $a h p C$ and $k a t A$ and the significance of $a h p C$ in protection from hydrogen peroxide in Xanthomonas campestris. FEMS Microbiol. Lett. 2005, 249, 73-78. [CrossRef] [PubMed]

67. Fukumori, F.; Kishii, M. Molecular cloning and transcriptional analysis of the alkyl hydroperoxide reductase genes from Pseudomonas putida KT2442. J. Gen. Appl. Microbiol. 2001, 47, 269-277. [CrossRef] [PubMed]

68. Loprasert, S.; Atichartpongkun, S.; Whangsuk, W.; Mongkolsuk, S. Isolation and analysis of the Xanthomonas alkyl hydroperoxide reductase gene and the peroxide sensor regulator genes ahpC and ahpF-oxyR-orfX. J. Bacteriol. 1997, 179, 3944-3949. [CrossRef]

69. Sherman, D.R.; Mdluli, K.; Hickey, M.J.; Arain, T.M.; Morris, S.L.; Barry, C.E., 3rd; Stover, C.K. Compensatory ahpC gene expression in isoniazid-resistant Mycobacterium tuberculosis. Science 1996, 272, 1641-1643. [CrossRef] 
70. Wilson, T.; de Lisle, G.W.; Marcinkeviciene, J.A.; Blanchard, J.S.; Collins, D.M. Antisense RNA to $a h p C$, an oxidative stress defence gene involved in isoniazid resistance, indicates that AhpC of Mycobacterium bovis has virulence properties. Microbiology 1998, 144, 2687-2695. [CrossRef]

71. Zhang, B.; Gu, H.; Yang, Y.; Bai, H.; Zhao, C.; Si, M.; Su, T.; Shen, X. Molecular Mechanisms of AhpC in Resistance to Oxidative Stress in Burkholderia thailandensis. Front. Microbiol. 2019, 10, 1483. [CrossRef] [PubMed]

72. Wang, G.; Conover, R.C.; Benoit, S.; Olczak, A.A.; Olson, J.W.; Johnson, M.K.; Maier, R.J. Role of a bacterial organic hydroperoxide detoxification system in preventing catalase inactivation. J. Biol. Chem. 2004, 279. [CrossRef] [PubMed] 